\title{
SLOPE INSTABILITY DRILLING PROGRAM, TONSINA HILL, ALASKA
}

T.D. Hubbard

Preliminary Interpretive Report 2017-1

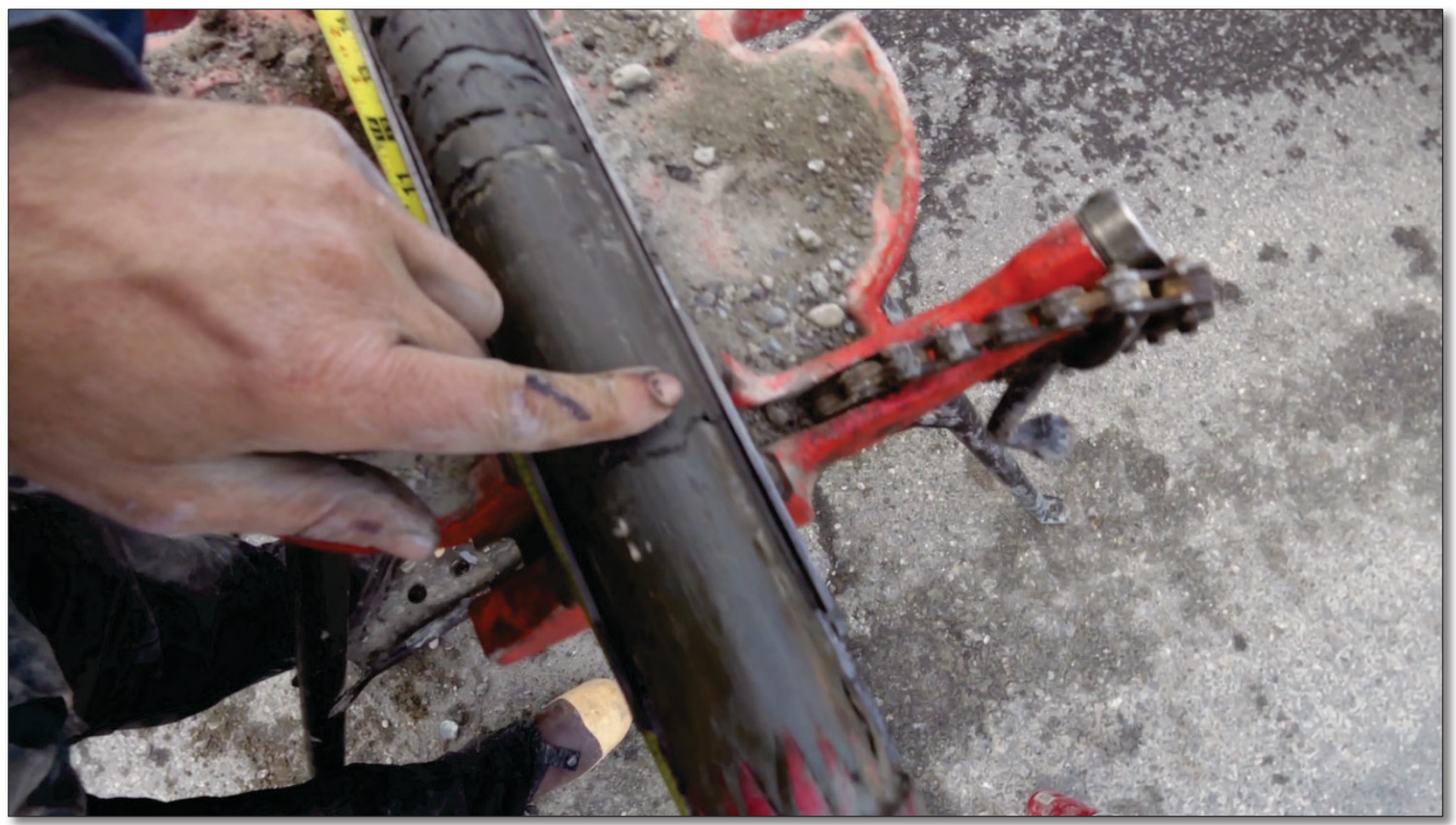

Examining core drilled from hole TDH 15-3305, showing typical low-plasticity clay from the study area. Photo by T.D. Hubbard.

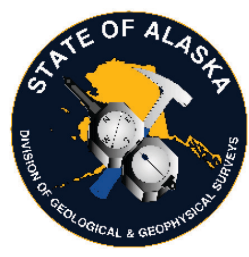

STATE OF ALASKA | DEPARTMENT OF NATURAL RESOURCES | DIVISION OF GEOLOGICAL \& GEOPHYSICAL SURVEYS 



\section{SLOPE INSTABILITY DRILLING PROGRAM, TONSINA HILL, ALASKA}

T.D. Hubbard

Preliminary Interpretive Report 2017-1

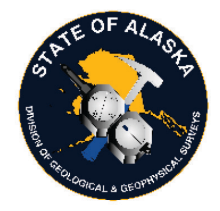

Alaska Department of Natural Resources

Division of Geological \& Geophysical Surveys

3354 College Road

Fairbanks, Alaska 99709-3707

(907) 451-5010

dggspubs@alaska.gov

dggs.alaska.gov 


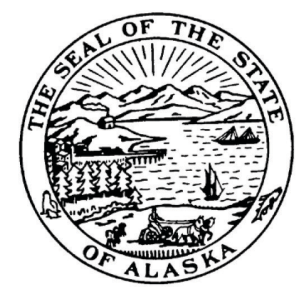

STATE OF ALASKA

Bill Walker, Governor

DEPARTMENT OF NATURAL RESOURCES

Andrew T. Mack, Commissioner

DIVISION OF GEOLOGICAL \& GEOPHYSICAL SURVEYS

Steve Masterman, State Geologist \& Director

Publications produced by the Division of Geological \& Geophysical Surveys are available for free download from the DGGS website (dggs.alaska.gov). Publications on hard-copy or digital media can be examined or purchased in the Fairbanks office:

\section{Alaska Division of Geological \& Geophysical Surveys (DGGS)}

3354 College Road | Fairbanks, Alaska 99709-3707

Phone: 907.451 .5010 | Fax 907.451.5050

dggspubs@alaska.gov | dggs.alaska.gov

DGGS publications are also available at:

\section{Alaska State Library, Historical Collections \& Talking Book Center 395 Whittier Street Juneau, Alaska 99801}

\author{
Alaska Resource Library \\ \& Information Services \\ 3150 C Street, Suite 100 \\ Anchorage, Alaska 99503
}


TABLE OF CONTENTS

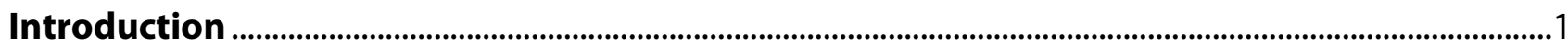

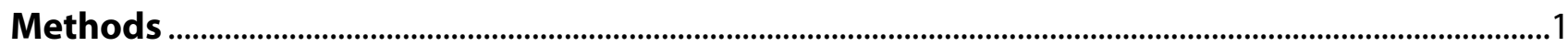

Drill Hole Descriptions .................................................................................................................................

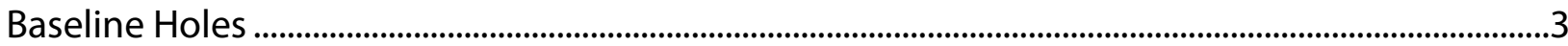

Station $81+25$ (offset 10L), TH 15-3300 ....................................................................................................................

Station 73+90 (offset 10L), TH 15-3301 ..............................................................................................................

Station 62+90 (offset 15R), TH 15-3311 ............................................................................................................

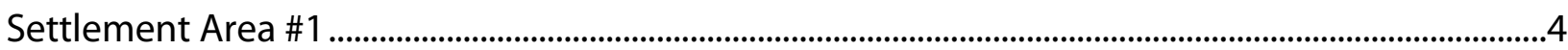

Station 78+60 (offset 15L), TH 15-3306 ...........................................................................................................

Station 77+70 (offset 15R), TH 15-3307 ………………………………………………………………………..

Station 77+75 (offset 15R), TH 15-3308 ………………………………………………………………….....

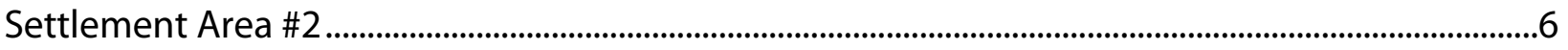

Station $69+10$ (offset 10R), TH 15-3302 …………………………………………………………………………6

Station 66+40 (offset 5L), TH 15-3303 ........................................................................................................................

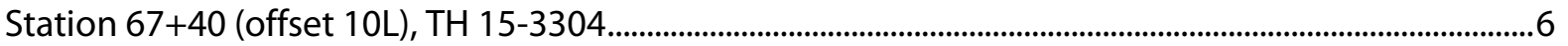

Station $65+50$ (offset 5R), TH 15-3305 ........................................................................................................

Station 71+15 (offset 10R), TH 15-3309 ………………………………………………………………………....

Station 70+20 (offset 15R), TH 15-3310 …………………………………………………………………………...

Inclinometer Hole ........................................................................................................................................

Station 66+90 (offset 80R), TH 15-3312 …………………………………………………………………….......

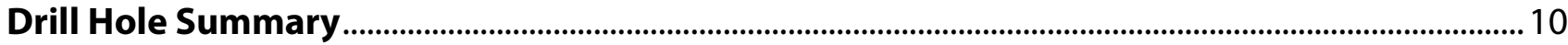

Baseline Holes ......................................................................................................................................... 10

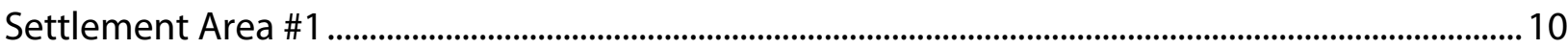

Settlement Area \#2 ……………………………………………………………………………………….... 10

Inclinometer Hole ......................................................................................................................................... 10

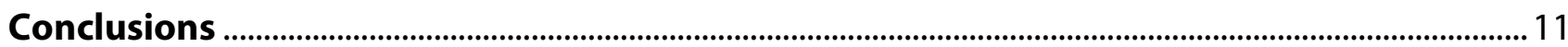

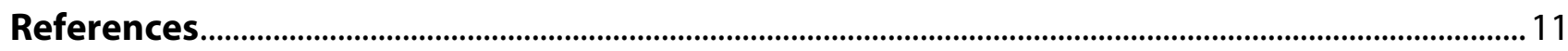

Appendix A: Draft Test Hole Logs ........................................................................................................... 13

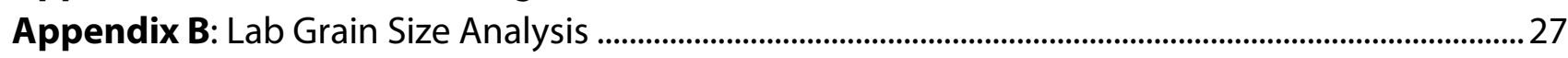

Appendix C: Moisture and Organic Content ............................................................................................. 34

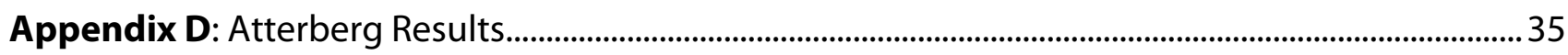

Appendix E: Drill Hole Temperature Data .....................................................................................................

\section{FIGURES}

1. Map showing Tonsina Hill study area and locations of boreholes and road settlement ...............2

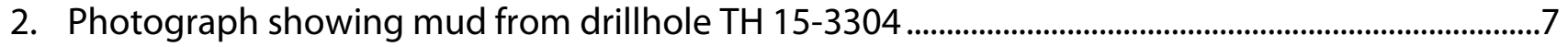





\section{SLOPE INSTABILITY DRILLING PROGRAM, TONSINA HILL, ALASKA}

Trent D. Hubbard ${ }^{1}$

\section{INTRODUCTION}

This report presents the results from geologic evaluation of several drill holes in an area of slope instability north of the Tonsina River, performed by the State of Alaska Division of Geological \& Geophysical Surveys (DGGS), through a Reimbursable Services Agreement with the State of Alaska Department of Transportation \& Public Facilities (DOT\&PF). The area of evaluation, locally known as Tonsina Hill, is between Valdez and Glennallen along the Richardson Highway between mileposts 80 and 82 (fig. 1).

The Richardson Highway is the only road connecting Valdez to interior Alaska, and it is vital to the movement of people and transportation of cargo in support of the Alaska economy. Many Alaskans use this transportation route to Valdez to access goods and services as well as to reach important hunting and fishing grounds. Tons of freight are transported between the coastal deep-water port in Valdez and other areas of Alaska. Additionally, the road is heavily used by tourists visiting the state, and supports traffic and personnel maintaining the TransAlaska Pipeline System (TAPS), an important economic driver of the state's economy. Any disruption to the traffic could have a significant impact on Alaskans.

DOT\&PF is planning to resurface this short section of the Richardson Highway north of the Tonsina River in an area locally known as Tonsina Hill. This north-climbing segment along an east-facing cut historically has been affected by slope movement and drainage issues (Brazo, 1989; Rasmussen, 1970). In the 1970s this road was realigned farther west to allow for construction of downslope counterweight buttresses to improve overall stability. However, after the project was completed, new settlement began to occur; the settling was attributed to slope movement exacerbated by poorly controlled discharge from springs. A pronounced bulge began to form in the late 1970s, which was later thought to be caused by progressive frost heave from water under pressure. A system of underdrains was eventually installed in the early 1990s to alleviate this condition.

At present, minor embankment settling has occurred north of and within the northern portion of the underdrain system (Settlement Area \#1 [SA\#1]), and significant embankment settling is associated with the southern portion of the underdrain system (Settlement Area \#2 [SA\#2]).

\section{METHODS}

During an October 19-23, 2015, field campaign, DGGS collaborated with DOT\&PF to drill 12 boreholes to better understand the mechanisms of slope movement and thaw-settlement problems (fig. 1). Eleven holes were drilled through the road surface; one hole was drilled east of the highway for installation of a slope inclinometer.

Of the 11 holes drilled through the road surface, three were baseline holes located outside the unstable regions. Three holes were drilled in SA\#1 and six in SA\#2, the northern and southern areas of known instability (fig. 1). Locations for holes in the areas of instability were chosen based on their proximity to road damage or noticeable slope disturbance, on the premise that information from drilling might provide useful information about their causes.

The location for drill hole TH 15-3312, east of the Richardson Highway, was chosen because of its proximity to the bulge that began to form on the slope in the late 1970s. This hole was drilled to a depth of 82 feet to gather information about the cause of the bulge, and also so that casing could be installed for slope inclinometer measurements. After the casing was installed baseline data were collected on October 28, 2015. These data will

${ }^{1}$ Alaska Division of Geological \& Geophysical Surveys, 3354 College Road, Fairbanks, Alaska 99709-3707; trent.hubbard@alaska.gov 

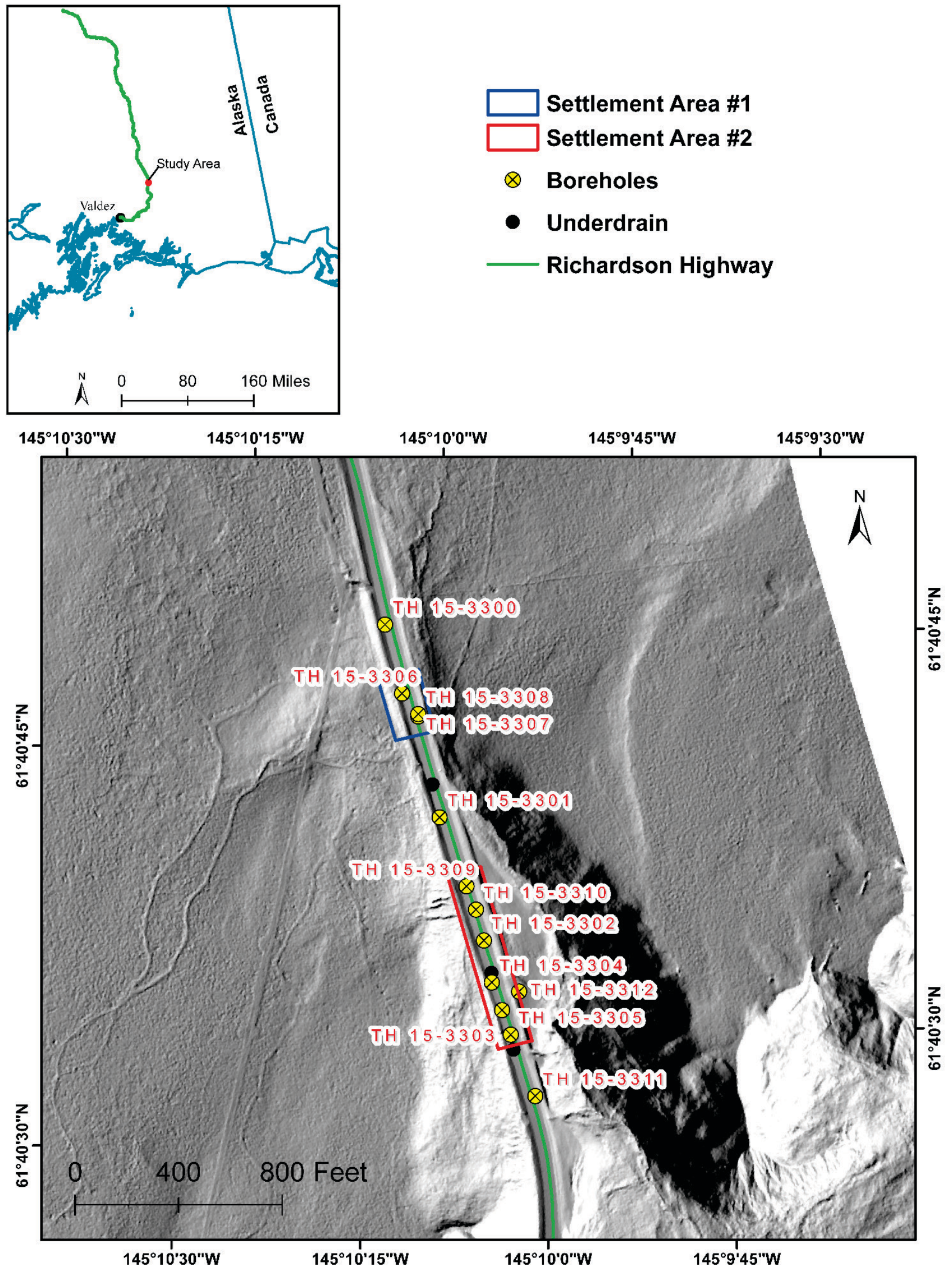

Figure 1. Map showing Tonsina Hill study area and locations of boreholes and road settlement. 
be compared with future data to better understand the nature of slope movement and identify potential shear zones.

Holes were drilled using a CME-55 truck with a 3-inch SIPRE auger with 5-foot-long flights. A 2-foot-long, 1.75-inch-diameter, split-spoon sampler was used to collect sediment samples, which allowed examination of minimally disturbed sediment. An automatic hammer was used to determine blow counts-the number of hammer strikes it takes for a split-spoon sampler to penetrate 6 inches. The $\mathrm{N}$ value is the total number of hammer strikes it takes for a split-spoon sampler to penetrate the second and third of four 6-inch intervals.

During drilling, sediment was evaluated and described based on the Alaska Field Guide for Soil Classification definitions (DOT\&PF Staff, 2003). Information about the sediment character, grain size, density, moisture, organic content, temperature, and overall site characteristics were recorded and sediment was classified according to the Unified Soil Classification System (USCS). After returning from the field, data for each drill hole were entered into DOT\&PF's gINT database, borehole logs were prepared, and samples were sent to the DOT\&PF materials lab for further analysis.

\section{DRILL HOLE DESCRIPTIONS}

\section{BASELINE HOLES}

As a basis for comparison, three holes were drilled outside the regions of slope instability. One hole (TH 153300) was drilled north of SA\#1, one hole was drilled between SA\#1 and SA\#2 (TH 15-3301), and one hole was drilled south of SA\# 2 (TH 15-3311) (fig. 1).

\section{Station 81+25 (offset 10L), TH 15-3300}

Hole TH 15-3300 (fig. 1) was drilled to a depth of 30 feet (appendix A). The surface was covered by 2.5 inches of asphalt. Based on field observations and grain-size analysis of sample TH 15-3700, collected from a drill depth of between 2.5 and 4 feet (appendix B), the fill below the surface asphalt is well-graded sand with gravel (SW) that transitions to well-graded sand with silt and gravel (SW-SM). In the 2-foot split-spoon sample interval (SSI) beneath the asphalt, the fill material is dry to moist, dense, and has an $\mathrm{N}$ value of 37 . Field observations indicate a slight increase in gravel content at a depth of $\sim 2$ feet.

At a drill depth of $\sim 4$ feet, silt content increases and the fill becomes moist to wet and field observations indicate the material is loose.

From the base of the fill layer at a depth of $\sim 5$ feet to the bottom of the drill hole ( 30 feet), the sediment is silty clay (CL-ML). The sediment has a firm to very stiff consistency with N values between 6 and 16. Sample TH 153702, collected between 5.8 and 6.6 feet depth, has a moisture content of 12.9 percent (appendix C); sample TH 15-3704, collected from the SSI between 10 and 12 feet, has a moisture content of 15.1 percent (appendix C).

Sample TH 15-3703, collected from the sample interval between 7.5 and 9.5 feet, has a medium plasticity (appendix D). Field observations indicate the clay to be somewhat silty, thus classifying it as CL-ML.

Although organics were not seen in field observations, sample TH 15-3706, collected from a drill depth of 22-25 feet, has an organic content of 2.4 percent (appendix C).

Sediment temperatures measured during field data collection were well above freezing $-44.8^{\circ} \mathrm{F}$ in the SSI between 7.5 and 9.5 feet and $45.5^{\circ} \mathrm{F}$ in the SSI between 20 and 22 feet (appendix E).

\section{Station 73+90 (offset 10L), TH 15-3301}

Hole TH 15-3301, drilled to a depth of 30 feet, is between SA\#1 and SA\#2 (fig. 1; appendix A). The embankment adjacent to the road near this hole is 5-7 feet thick. At the surface is a 2.5-inch layer of asphalt. Based on field observations and grain-size analysis of sample TH 15-3710 (appendix A), collected from the drill interval 
between 5 and 7.5 feet, the fill beneath the asphalt to a depth of $\sim 8.3$ feet is a dry, poorly graded gravel, with silt and sand (GP-GM). The sediment is dense ( $\mathrm{N}$ value of 43 ) in the 2 foot sample interval beneath the asphalt, and very dense ( $\mathrm{N}$ value of 74 ) in the SSI between 2.5 and 4.5 feet.

From the base of the fill layer at $~ 8.3$ feet and continuing to the bottom of the drill hole, the sediment is predominantly silty clay (CL-ML). Sediment sample TH 15-3714, collected from the SSI between 20 and 22 feet, is a medium-plasticity, silty clay (CL-ML) (appendix D).

The CL-ML unit has some gravel to a depth of $~ 13$ feet but this coarse fraction decreases in abundance with depth. Moisture content of sample TH 15-3712, collected from the SSI between 10 and 12 feet, is 18.4 percent (appendix C). Field observations indicate sediment in this interval is wet, thixotropic, and soft, with an $\mathrm{N}$ value of 4 .

At drill depths below 15 feet, $\mathrm{N}$ values of 7 and 8 indicate sediment is firm, but field observations indicate local areas of increased moisture where the sediment is soft. Varves are present in the sample interval between 25 and 27 feet, suggesting that the silty clays may be lacustrine.

Sediment temperature measured in the SSI between 15 and 17 feet was $44^{\circ} \mathrm{F}$, well above freezing (appendix E). No ice was present in the sediment; no evidence of permafrost was found in this drill hole.

\section{Station 62+90 (offset 15R), TH 15-3311}

Hole TH 15-3311, south of SA\#2, was drilled to a depth of 32.5 feet (fig. 1; appendix A). The embankment adjacent to the road near this drill hole is $8-10$ feet thick. At the surface are 2 inches of asphalt. Below this, to a depth of 2.1 feet, the material is well-graded sand with gravel (SW). The fill material in the 2 -foot sample interval beneath the asphalt is dry to somewhat moist and very dense, with an $\mathrm{N}$ value of 50 .

Sample TH 15-3763, collected from between 2.7 and 5 feet, indicates that below the SW, to a depth of $\sim 5$ feet, is a layer of silty sand with gravel (SM) (appendix B).

From the bottom of the fill at a depth of 5 feet to $\sim 13.5$ feet the sediment is slightly moist, silty clay (CL-ML). The sample interval has $\mathrm{N}$ values of 7 between 5 and 7 feet and 11 for the interval between 10 and 12 feet, indicating the sediment is firm to stiff.

From a depth of 13.5 feet to the bottom of the hole at 32.5 feet the sediment is well-graded sand, with varying amounts of silt and gravel except for poorly graded sand with silt between a depth of 16.5 and $\sim 18.3$ feet. The sand is generally dry to somewhat moist. An $\mathrm{N}$ value of 48 in the interval between 17.5 and 19.5 feet and an $\mathrm{N}$ value of 57 in the interval between 25 and 27 feet indicate that the sand- and gravel-rich sediment between 13.5 and 32.5 feet depth transitions from firm/stiff to dense/very dense.

A sediment temperature of $41.5^{\circ} \mathrm{F}$ in the interval between 10 and 12 feet indicates a lack of permafrost in the silty clay (appendix E). There was no ice or evidence of permafrost in this drill hole.

\section{SETTLEMENT AREA \# 1}

\section{Station 78+60 (offset 15L), TH 15-3306}

Hole TH 15-3306 is in SA\#1 (fig. 1; appendix A). At the surface is a 2.5-inch layer of asphalt, below which we measured 12 inches of poorly graded gravel with sand (GP). Below this, to a depth of $\sim 7.6$ feet, is well-graded sand with gravel (SW). The fill is medium dense in the 2 -foot interval below the asphalt ( $\mathrm{N}$ value of 27) and in the interval between 5 and 7 feet ( $\mathrm{N}$ value of 26). A change in drilling character related to cobbles encountered between 2.21 and 5 feet, and a change in fill material to a well-graded sand layer with silt and gravel (SW-SM) in the interval between 3.5 and 5.3 feet, demonstrate variability in grain size over the depth of the SW unit. Sample TH 15-3344, collected from SW-SM sediment between 5 and 5.3 feet depth, has a moisture content of 6.8 percent 
(appendix C). Field observations indicate the sediment in this interval has a higher moisture content than the overlying, well-graded sand and gravel (SW).

At a depth of 7.6 feet, beneath the fill, sediment becomes silty clay (CL-ML) to the bottom of the hole at 32.5 feet. In the SSI between 7.5 and 9.5 feet the sediment is stiff with an $\mathrm{N}$ value of 10 . At greater depths the $\mathrm{N}$ value varies from 4 to 7 , and sediment is generally firm. Moisture content of sample TH 15-3748 in the 30 to 32 foot SSI is 15.8 percent (appendix C).

The sediment temperature measured in the SSI between 17.5 and 19.5 feet was $40^{\circ} \mathrm{F}$ and the sediment temperature measured from the interval between 30 and 32 feet was $36.1^{\circ} \mathrm{F}$ (appendix E). Measured sediment temperatures above freezing and lack of ice in sediment indicate permafrost was not present in this drill hole.

\section{Station 77+70 (offset 15R), TH 15-3307}

Hole TH 15-3307 is in SA\#1 (fig. 1; appendix A). The embankment thickness is $~ 5$ feet. At the surface is a 9-inch layer of asphalt. Below this, to a depth of 3.5 feet, is poorly graded gravel with sand (GP). The fill material in the 2 foot sample interval below the asphalt is dense, with an $\mathrm{N}$ value of 42 . Within the GP unit between $\sim 1.9$ and $\sim 2.1$ feet is a 2 -inch layer of asphalt.

At a depth of 3.5 feet is another 2-inch layer of asphalt. Beneath this, to a depth of $\sim 6$ feet, the fill is well-graded sand with gravel (SW). An $\mathrm{N}$ value of 16 for the interval between $\sim 3.25$ and 5 feet indicates the material in this interval is medium dense.

A grain-size analysis of sample TH 15-3749 (appendix B), collected from a depth between 5 and 7.5 feet, along with field observations, indicates that as the silt component of the SW increases the material becomes wellgraded sand with silt and gravel (SW-SM) to the bottom of the hole at 17.5 feet. An N value of 26 for the sample interval between 7.5 and 10 feet indicates the SW-SM fill is medium dense.

From a drill depth of 15 to 17.5 feet the fill is very wet, appearing saturated. On removal of the drill auger, mud began filling in the hole, forcing drilling to cease. Moisture content of sample TH 15-3750, collected in the sample interval between 15 and 17.5 feet, is 18 percent (appendix C).

No sediment temperature data were collected during drilling and ice was not observed. Abundant liquid water suggests permafrost was not present.

\section{Station 77+75 (offset 15R), TH 15-3308}

Hole TH 15-3308 is in SA\#1 and is only 5 feet west of drill hole TH 15-3307 (fig. 1; appendix A). The embankment thickness is $\sim 5$ feet and the road surface is covered with 9 inches of asphalt. Below this to a depth of $\sim 12.8$ feet is a well-graded sand with silt and gravel (SW-SM). From 10 to $\sim 12.8$ feet the material is very wet. In the SSI between 10 and 12 feet the sediment is loose, with an $\mathrm{N}$ value of 9 .

At $\sim 12.8$ feet the fill material transitions to a very wet, silty, clayey sand (SC-SM). In the 15 to 17 foot SSI the sediment is loose with an $\mathrm{N}$ value of 8 and a moisture content of 15.4 percent (sample TH 15-3753; appendix C).

At 20.7 feet, the sediment becomes silty clay (CL-ML) to the bottom of the hole at 30 feet. When the drill auger was removed at depths below 17 feet, wet sediment slowly filled the hole. In the interval between 25 and 27 feet the silty clay is soft, with an $\mathrm{N}$ value of 3 .

The sediment temperature in the sample interval between 25 and 27 feet was $40^{\circ} \mathrm{F}$ (appendix E). No ice was observed in the sediment, and no evidence of permafrost was found in this drill hole. 


\section{SETTLEMENT AREA \#2}

\section{Station 69+10 (offset 10R), TH 15-3302}

Hole TH 15-3302 is in SA\#2 (fig. 1; appendix A). The embankment thickness is 5-7 feet and the asphalt layer at the top of the road is 4.5 inches thick. Below the asphalt, most of the fill material to a depth of $\sim 12$ feet is a generally dry to moist, poorly graded gravel with silt and sand (GP-GM) except between a depth of 4.5 and 6.42 feet where, based on field observation, it is wet to moist. The SSI between 4.5 and 5.8 feet is poorly sorted sand with gravel (SP) that has a moisture content of 7.6 percent (sample TH 15-3719; appendix C).

The material in the 2 foot sample interval beneath the asphalt is very dense ( $\mathrm{N}$ value of 53) but is medium dense between 2.5 and 4.5 feet ( $\mathrm{N}$ value of 25) and between 5 and 7 feet ( $\mathrm{N}$ value of 14). The fill is dense, with an $\mathrm{N}$ value of 36 , in the interval between 7.5 and 9.5 feet.

Based on drill reaction there are $\sim 6$ inches of wet silt starting at a depth of 12 feet. Below this, the sediment is silty clay (Cl-ML) to the bottom of the hole at 30 feet. The silty clay has medium plasticity (sample TH 15-3720; appendix D) and is firm, with an $\mathrm{N}$ value of 5, in the interval between 12.5 and 14.5 feet. In the SSI between 15 and 17 feet the sediment is also firm, with an N value of 5. Sample TH 15-3722, collected from the interval between 20 and 22.5 feet, is soft and has a moisture content of 18.9 percent (appendix C). Field observations indicate an increase in moisture at a drill depth of about 27.5 feet, manifested by an increase in the amount of visible water; otherwise, the silty clay is generally moist.

Sediment temperature measured in the SSI between 15 and 17 feet was $40.5^{\circ} \mathrm{F}$, and was $34.3^{\circ} \mathrm{F}$ in the interval between 27.5 and 29.5 feet (appendix E). No ice or evidence of permafrost was found in sediment from this drill hole. However, temperatures near the bottom of the hole are approaching freezing.

\section{Station $66+40$ (offset 5L), TH 15-3303}

Hole TH 15-3303 is in SA\#2 (fig. 1; appendix A). The embankment thickness is between 6 and 8 feet. At the road surface is a $\sim 16$-inch layer of asphalt. Below this is a 4 -inch layer of dark brown, poorly graded gravel, with silt and sand (GP-GM), which has the appearance of an old asphalt layer. Below this probable asphalt layer, to a depth of 4.1 feet, is dry to moist, well-graded sand with silt and gravel (SW-SM). The fill material in the 2 foot sample interval below the surface asphalts is very dense, with an $\mathrm{N}$ value of 55 .

From a depth of $\sim 4.1$ to $\sim 10$ feet the fill is poorly graded gravel with silt and sand (GP-GM). Blue foam and cobbles were observed at the bottom of the sample interval between 5 and 7 feet and the fill in this interval is moist and medium dense, with an $\mathrm{N}$ value of 18 .

At depth of 10 feet, extending to a depth of 11.4 feet, is a moist to wet, well-graded sand (SW-SM) with silt and gravel, with a moisture content of 8.6 percent (sample TH 15-3726; appendix C).

Starting at a depth of $\sim 11.4$ feet and continuing to the bottom of the drill hole at 30 feet, the sediment is silty clay (CL-ML). This sediment is soft, with $\mathrm{N}$ values of 2-4. Sediment sample TH 15-3728, collected from between 17.5 and 19.7 feet, is moist to wet with a moisture content of 23.7 percent (appendix C).

A sediment temperature of $39.4^{\circ} \mathrm{F}$ was measured in the interval between 12.5 and 14.5 feet and a sediment temperature of $36^{\circ} \mathrm{F}$ was measured between 25 and 27 feet (appendix E). No ice or evidence of permafrost was observed in the sediment from this drill hole.

\section{Station 67+40 (offset 10L), TH 15-3304}

Hole TH 15-3304 is in SA\#2 (fig. 1; appendix A). The thickness of the embankment is 5-8 feet; at the road surface is a 6-inch layer of asphalt. Below this are 4 inches of well-graded sand with gravel (SW) that have an overall appearance of degraded asphalt. Below this a dry, well-graded sand with gravel (SW) continued to a 
depth of about 6 feet, where a 3-inch cobble was encountered during drilling. The fill material in the 2.5-foot interval below the surface asphalt is very dense, with an $\mathrm{N}$ value of 61 .

Beneath the cobble, to the bottom of the drill hole at 30 feet, the sediment is silty clay (CL-ML) that is generally soft, with $\mathrm{N}$ values of 2 and 4 except in the interval between 15 and 17 feet, where an $\mathrm{N}$ value of 6 indicates it is firm. Sample $\mathrm{TH} 15-3732$, collected from the 10 to $\sim 12$ foot SSI, is silty clay with medium plasticity (appendix D). Although no organics were observed, sample $\mathrm{TH}$ 15-3733 collected from the 15 to 17 foot SSI, has an organic content of 1.3 percent (appendix C).

In general, most of the CL-ML sedi-

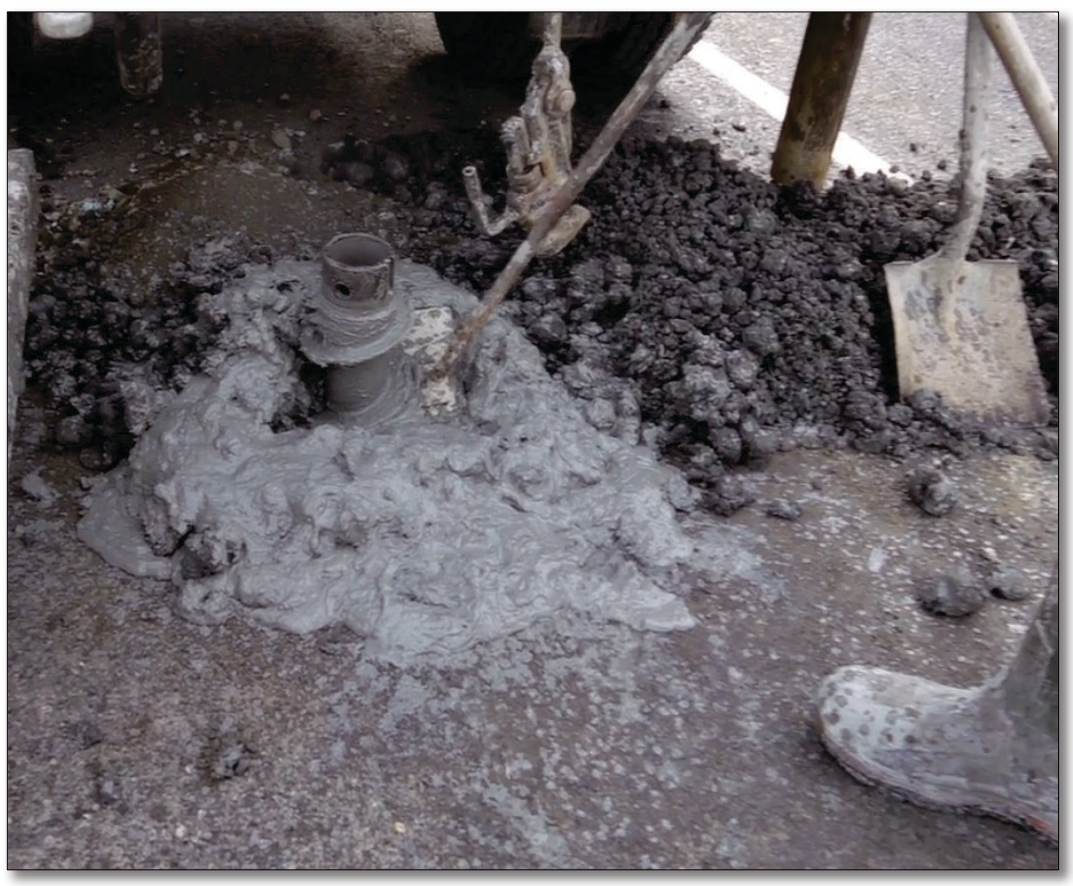

Figure 2. Photograph showing mud from drill hole TH 15-3304. ment in this drill hole is moist to wet. At a drill depth of 12.5 feet the sediment was very wet (fig. 2) and groundwater partially filled the drill hole on removal of the auger.

At a sample interval between 25 and 27 feet, ice needles were observed in the sediment and water was present in the split-spoon sample. Sample TH 15-3735 from this interval had a moisture content of 21.1 percent (appendix C).

The sediment temperature measured in the interval between 25 and 27 feet was $32.1^{\circ} \mathrm{F}$ (appendix E). At shallower depths sediment temperatures ranged from $39.1^{\circ} \mathrm{F}$ to $40^{\circ} \mathrm{F}$.

\section{Station $65+50$ (offset 5R), TH 15-3305}

Hole TH 15-3305 is at the south end of SA\#2 (fig. 1; appendix A). At the surface is a 4 inch layer of asphalt. Beneath this are 6 inches of well-graded sand with gravel (SW), which becomes well-graded sand with silt and gravel (SW-SM) to a depth of $\sim 4.5$ feet. The fill material in the 2 -foot-long sample interval beneath the asphalt $(\mathrm{N}$ value of 50) and in the interval between 3 and 5 feet $(\mathrm{N}$ value of 31$)$ are both dense.

Sample TH 15-3737, collected from a depth of between 5 and 7.5 feet, is silty gravel with sand (GM) (appen$\operatorname{dix}$ B). Beneath the GM unit, from a depth of $\sim 7.6$ to $\sim 20$ feet, sediment is moist to wet, silty clay (CL-ML). The moisture content of sample TH 15-3738, collected from CL-ML sediment between 7.6 and 9.4 feet, is 29.8 percent (appendix C). The CL-ML sediment is soft, with an $\mathrm{N}$ value of 4, in the intervals between 7.5 and 9.5 feet and between 10 and 12 feet. However, the sediment is firm, with an N value of 7, in the SSI between 15 and 17 feet.

Beginning at a depth of 20 feet there is a 3-inch layer of moist to wet, poorly graded sand (SP), below which are 3 inches of moist to wet silt with sand (ML). Beneath the ML unit is a 6-inch layer of moist, silty clay with sand (CL-ML), below which is moist, poorly graded gravel with sand (GP) to a depth of $\sim 23.25$ feet. The sediment in the sample interval between 20 and 22 feet is very dense, with an $\mathrm{N}$ value of 88 .

Sediment from the sample interval between 25 and 27 feet is moist to wet, very dense ( $\mathrm{N}$ value of 87 ) silty sand with gravel (SM) that extends from 23.25 feet to the bottom of the hole at 30 feet. 
Sediment temperature measured in the sample interval between 7.5 and 9.5 feet was $42^{\circ} \mathrm{F}$ and in the interval between 10 and 12.5 feet was $44^{\circ} \mathrm{F}$ (appendix E). The sediment temperature taken from the ML sediment in the sample interval between 20 and 22 feet was $40^{\circ} \mathrm{F}$. Sediment in this hole did not exhibit any evidence of permafrost.

\section{Station 71+15 (offset 10R), TH 15-3309}

Hole TH 15-3309 is in SA\#2 (fig. 1; appendix A). At the surface are 4 inches of asphalt. Beneath this, to a depth of $\sim 5.85$ feet, is poorly graded gravel with sand (GP). In the sample interval between 2.5 and 4.5 feet the fill is dry to moist and medium dense with an $\mathrm{N}$ value of 30 .

From 5.85 to 7.75 feet is a well-graded sand with silt (SW-SM). The sediment below this, to the bottom of the hole at 32.5 feet, is silty clay (CL-ML). N values between 4 and 8 indicate the CL-ML sediment is soft to firm. Sample TH 15-3755, collected from below the SW-SM unit in the 7.5 to 9.5 foot SSI, is medium-plasticity, silty clay (CL-ML; appendix D).

At a depth of 25 feet, and continuing to the bottom of the hole, we observed an increase in sediment moisture in the silty clay. Here the sediment is moist to wet, compared to moist at depths less than 25 feet.

Sediment temperatures decrease with depth from $42^{\circ} \mathrm{F}$ in the sample interval between 7.5 and 9.5 feet, to $35.5^{\circ} \mathrm{F}$ in the interval between 30 and 32 feet (appendix E). No ice was observed in sediment from this drill hole; however, temperatures at the bottom of the drill hole approach freezing and permafrost could be present below the depth of drilling.

\section{Station 70+20 (offset 15R), TH 15-3310}

Hole TH 15-3310 is in SA\#2 (fig. 1; appendix A). The embankment thickness is $\sim 5$ feet and the surface consists of 3 inches of asphalt. Beneath this, to a depth of $\sim 4.75$ feet, where the drilling character changed, is well-graded sand with gravel (SW). In the 2-foot sample interval below the asphalt, the fill material is generally dry and dense, with an $\mathrm{N}$ value of 40 .

From a depth of 4.75 to $~ 9.5$ feet, the fill is poorly graded gravel with sand (GP) that is generally dry. Material in the interval between 5 and 7 feet is medium dense, with an $\mathrm{N}$ value of 23 . At 9.5 feet fill changes from GP to well-graded sand with silt and gravel (SW-SM). The depth of sediment change was determined based on an increase in moisture content observed during drilling at 9.5 feet, and 2 inches of well-graded sand with silt (SWSM) that was observed at the beginning of the interval between 10 and 12 feet.

Field observation of material character in the sample interval between 10 and 12 feet and grain size analysis of sample TH 15 3759, collected from the interval between 12.5 and 15 feet (appendix B), indicate that underlying SW-SM is moist to wet silt with sand (ML) to a depth of 15 feet. An N value of 31 in the sample interval between 10 and 12 feet indicates the ML is dense.

From a drill depth of 15 feet to the bottom of the hole, at a depth of 32.5 feet, sediment is silty clay (CL-ML). An $\mathrm{N}$ value of 5 in the interval between 15 and 17 feet indicates the CL-ML is firm at the top of this interval but an $\mathrm{N}$ value of 3 in the interval between 20 and 22 feet, and an N value of 4 in the interval between 25 and 27 feet indicate the sediment is generally soft at depth. An $\mathrm{N}$ value of 8 in the split-spoon sample interval between 30 and 32 feet indicates sediment is slightly more firm at the bottom of the drill hole. The softer sediment is generally moist to wet or wet, while the firmer sediment is generally moist.

Sample TH 15-3760, collected from the 15 to 17 foot SSI, has a moisture content of 18.7 percent and sample TH 15-3762, collected from the 25 to 27 foot SSI, has a moisture content of 21.7 percent (appendix C). 
Sediment temperature in the sample intervals between 15 and 17 feet and between 20 and 22 feet were $38^{\circ} \mathrm{F}$ and $35^{\circ} \mathrm{F}$, respectively (appendix E). The sediment temperature in the interval between 25 and 27 feet was $31.1^{\circ} \mathrm{F}$, with visible ice. In the interval between 30 and 32 feet the sediment temperature was $34.1^{\circ} \mathrm{F}$.

\section{INCLINOMETER HOLE}

\section{Station 66+90 (offset 80R), TH 15-3312}

Hole TH 15-3312 is off the road, east of SA\#2 (fig. 1; appendix A). At the surface is a 2-inch organic layer, below which there is a $\sim 5$-inch layer of pebbles and cobbles. Beneath this are 3 inches of moist, well-graded sand with silt and gravel (SW-SM), which terminates at a 1-inch layer of broken pebbles. Beneath the broken pebble unit is silty, clayey sand with gravel (SC-SM). The material in the interval below the 5-inch pebble and cobble unit (from $\sim 0.5$ to 2.5 feet) is medium dense, with an $\mathrm{N}$ value of 13 .

Material encountered during drilling from a depth of $\sim 2.5$ to 7.5 feet, beneath the SC-SM unit, included a 6-inch broken clast from a boulder, a 5-inch unit of pebbles and cobbles, and moist, silty, clayey gravel with sand (GCGM). Based on observations from drilling, and analysis of sample TH 15-3770 (appendix B), collected from the interval between 7.5 and 10.2 feet, the GC-GM extends to a depth of $\sim 11.4$ feet. An N value of 6 for the interval between 7.5 and 9.5 feet and an N value of 8 in the interval between $\sim 9.5$ and $\sim 11.5$ feet indicate the GC-GM material is loose.

Beginning at 11.35 feet, the sediment is silty clay (CL-ML) to a depth of $\sim 53.5$ feet and then becomes a lean clay (CL) to a depth of 59 feet. Sediment sample TH 15-3772, collected in the 20 to 22 feet SSI, is medium-plasticity, silty clay (CL-ML; appendix D).

$\mathrm{N}$ values between 2 and 4 in the silty clay between 12.5 and 27 feet depth indicate it is generally soft through this interval. Generally, the sediment is moist except for between 25 and 27 feet, where it is wet. Sample TH 15-3771, collected from the 12.5 to 14.5 foot SSI, has a moisture content of 19.1 percent (appendix C).

An N value of 9 in the SSI between 30 and 32 feet indicates the CL-ML becomes stiff in this interval. Below this, to a depth of 52 feet, the sediment is firm, with $\mathrm{N}$ values of 5-7.

In the interval between 55 and 57 feet the sediment is again stiff, with an $\mathrm{N}$ value of 11 . The sediment between 30 and 57 feet is generally moist. Sample TH 15-3774, collected from the 45 to 47 foot SSI, has a moisture content of 27.6 percent (appendix C).

Although no organics were observed in the silty clay, sample TH 15-3773, collected from the 40 to 42 foot SSI, has a measured organic content of 2.3 percent (appendix C).

Beginning at a depth of 59 feet and continuing to 82.5 feet we observed a number of well-graded sand units, as well as very poorly graded sand (SP) from 72 to 76 feet and 78.5 to 81.5 feet and then poorly graded sand with gravel (SP) between 78.5 and 82.5 feet. The sand units are differentiated on the basis of color and the amount of silt and gravel. Sample TH 15-3776, from the SSI between 65 and 67 feet, has a moisture content of 8.0 percent (appendix C).

High blow counts of 70 and above in the SSIs from 60 to 62 feet, 65 to 67 feet, and 75 to 77 feet indicate the sand units are very dense. In general, the sand units are moist to dry.

Sediment temperatures in this hole were between $38^{\circ} \mathrm{F}$ and $41^{\circ} \mathrm{F}$, except in the interval between 12.5 and 14.5 feet, where the sediment temperature was $34.8^{\circ} \mathrm{F}$ and in the SSI between 55 and 57 feet near the base of a CLML layer, where the sediment temperature was $44.7^{\circ} \mathrm{F}$ (appendix E). 


\section{DRILL HOLE SUMMARY}

\section{BASELINE HOLES}

In the baseline drill holes, where settlement was less problematic, the road embankment material (generally the sand and gravel at the top of the drill logs) was, for the most part, dry or dry to moist and dense to very dense. Intervals of wet to moist sediment, such as the silty, clayey sand with gravel (SC-SM) from a depth of 4-4.6 feet in hole TH 15-3300, indicate local areas of increased moisture.

Below the sands and gravels the silty clay (CL-ML) was generally moist, and firm to stiff. Local areas of moist to wet silty clay (CL-ML) have elevated moisture levels, such as in the interval between 10 and 11 feet in drill hole TH 15-3301, where the moisture content is 18.4 percent.

In the baseline holes, no ice or other evidence of permafrost was found during drilling, and sediment temperatures were above freezing.

\section{SETTLEMENT AREA \# 1}

The sand and gravel from road embankment material in the drill holes in SA\# 1 is generally medium dense to dense and dry. However, some sand and gravel, such as between 5 and 7 feet in hole TH 15-3306, and between 7.5 and 15 feet in hole TH 15-3307, is moist to wet or wet, with a looser density. Moisture content is as high as 18 percent (sample TH 15-3750) at a depth of 15.2 to 16 feet in hole TH 15-3307, and in this interval saturated sediment flows into the drill hole after removal of the drill flight.

The silt and clay from holes in SA\#1 are moist and firm to stiff in hole TH 15-3306 but moist to wet and soft in hole TH 15-3308.

\section{SETTLEMENT AREA \#2}

While in general the sand and gravel from road embankment in drill holes in SA\#2 is medium dense to very dense and dry to moist, there are several intervals of increased moisture, such as between 5 and 5.8 feet in hole TH 15-3302 (moisture content 7.6 percent) and between 10 and 10.3 feet in hole TH 15-3303 (moisture content 8.6 percent). These wet intervals have lower blow counts, and thus lower $\mathrm{N}$ values and density than in the dry intervals.

Within the silty clays, numerous intervals have high moisture content, appear wet or moist to wet, and are soft. Ice was found in silty clay in hole TH 15-3304, where the temperature was measured at $32.1^{\circ} \mathrm{F}$. This sediment is very wet and soft, indicating that thawing permafrost can potentially add liquid water to sediment and increase the potential for instability. In hole TH $15-3302$ sediment temperatures were measured at $34.3^{\circ} \mathrm{F}$ at the bottom of the hole, indicating potential permafrost at greater depth.

\section{INCLINOMETER HOLE}

The sand in the upper part of the inclinometer hole, to a depth of about $7.5 \mathrm{feet}$, is moist and medium dense. As the sand changes to gravel at about 7.5 feet the sediment becomes loose and the moisture content is somewhat elevated in sample TH 15-3771 (19.1 percent). From a depth of $\sim 12.5$ to $\sim 30$ feet the silty clay is moist to wet and soft and then becomes moist and firm to stiff to a depth of $\sim 59$ feet. Below the silty clay, the sand and gravel is moist to dry and very dense to the bottom of the hole. 


\section{CONCLUSIONS}

Soil moisture is an important contributing factor to slope instability in this area. In baseline holes, road embankment sands and gravels tend to be dry and dense. In problematic settlement areas the sands and gravels often have wet intervals that are less dense. These wet intervals have reduced strength, making them more susceptible to failure. Better drainage would likely alleviate some of this problem.

In some places, such as at a depth of 10.4 feet in hole TH 15-3303, the lower density wet sands and gravels are underlain by silty clay units. Accumulation of water at the upper contact of the clay, where density increases and drainage is impeded, may produce failure along the surface between the different units. Results from repeat inclinometer measurements, which allow the evaluation of the relationship of movement to changes in sediment type, should help answer this question.

In the settlement area drill holes, much of the silty clay occurring below the road embankment material is moist to wet or wet, and soft, while in the baseline holes this sediment tends to be moist and firm to stiff. Moisture content of samples collected in the 17.5 to 20 foot SSI in hole TH 15-3303 (23.7 percent), in the 7.5 to 10 foot SSI in hole TH 15-3305 (29.8 percent), and in the 25 to 27 foot SSI in hole TH 15-3310 (21.7 percent), all in settlement areas, is higher than moisture content from a firm, silty clay collected from the 30 to 32 foot SSI in baseline hole TH 15-3306 (15.8 percent). While areas of higher moisture content are sometimes natural, it is also possibly a result of inadequate drainage. Higher moisture content and wet intervals in sands and gravels would allow excess moisture to slowly infiltrate into silty clays, reducing their strength and increasing the potential for instability.

Permafrost is another important factor in the stability of the slope. In an interval where ice was found, sediment was very wet and soft, and above the ice-rich material the sediment was soft. As permafrost thaws sediment will decrease in strength as ice changes to liquid water, and thus areas of permafrost, especially with high ice content, can be problematic. Also, dewatering can be difficult and slow in these silt- and clay-rich sediments, further exacerbating the problem.

\section{REFERENCES}

Brazo, G.M., 1989, Engineering geology and soils report; Richardson Highway mile 79 to 100: Alaska Department of Transportation \& Public Facilities, Northern Region Design and Construction, Project F-071-2 (28)/63390, $114 \mathrm{p}$.

Ramussen, J.D., 1970, Materials site report, centerline soils and materials sites investigation, north approach, Tonsina River, Richardson Highway: Alaska Department of Highways, Valdez District, Materials Division, Engineering Geology Section, Project F-071-2(7), 51 p.

DOT\&PF Staff, 2003, Alaska field guide for soil classification: Alaska Department of Transportation \& Public Facilities, $25 \mathrm{p}$. 
Preliminary Interpretive Report 2017-1 


\section{APPENDIX A}

DRILL HOLE LOGS

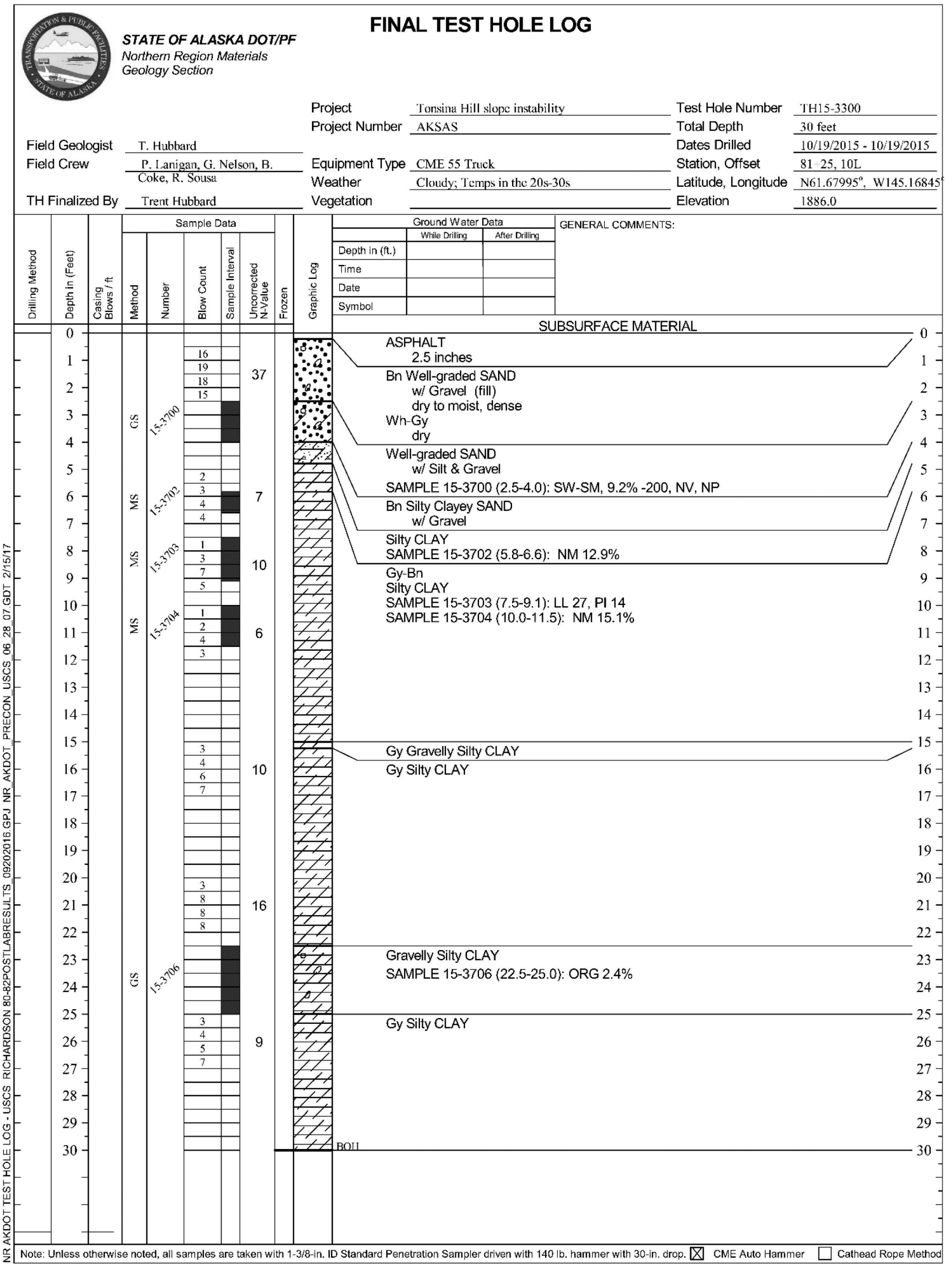




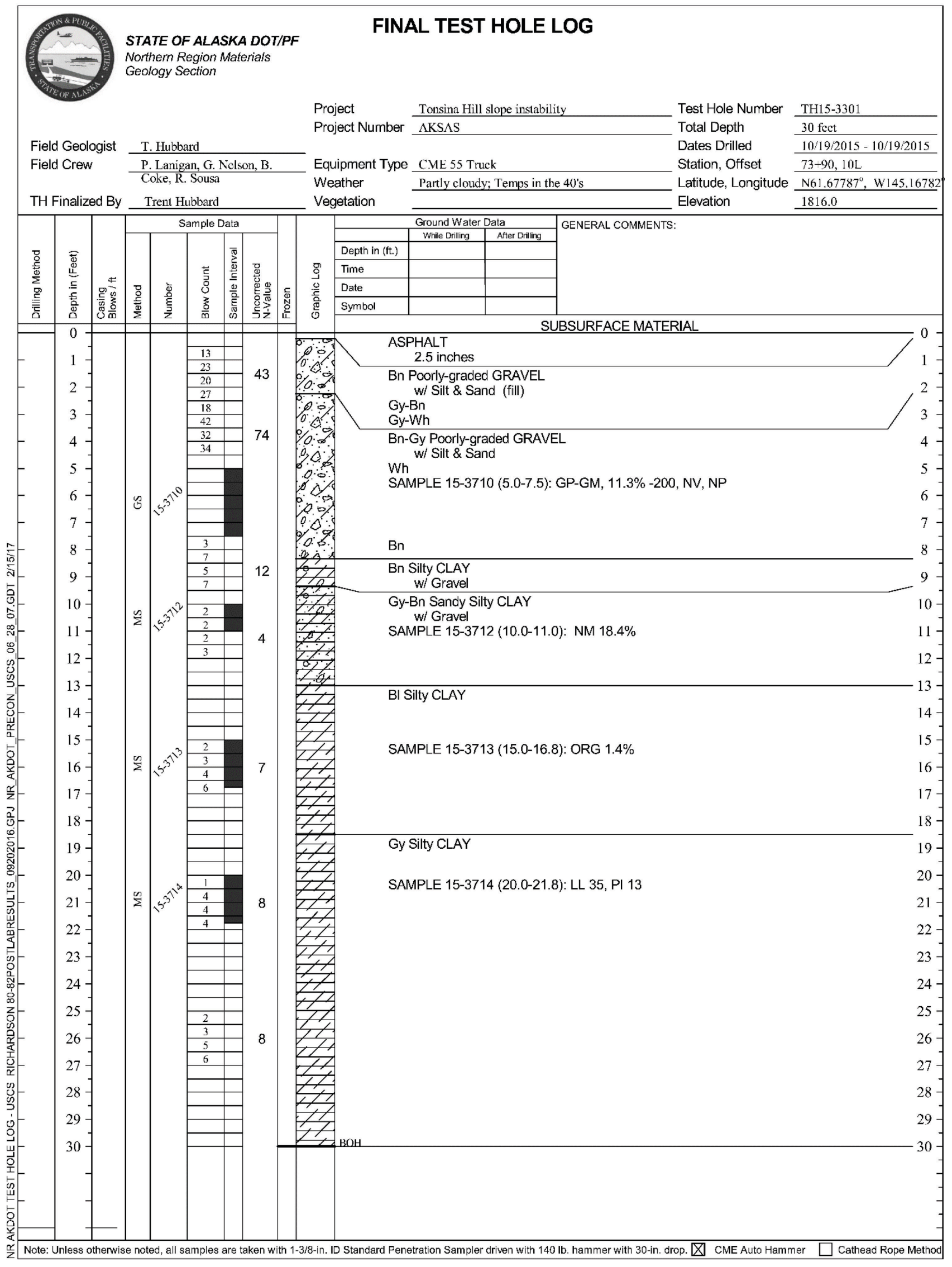




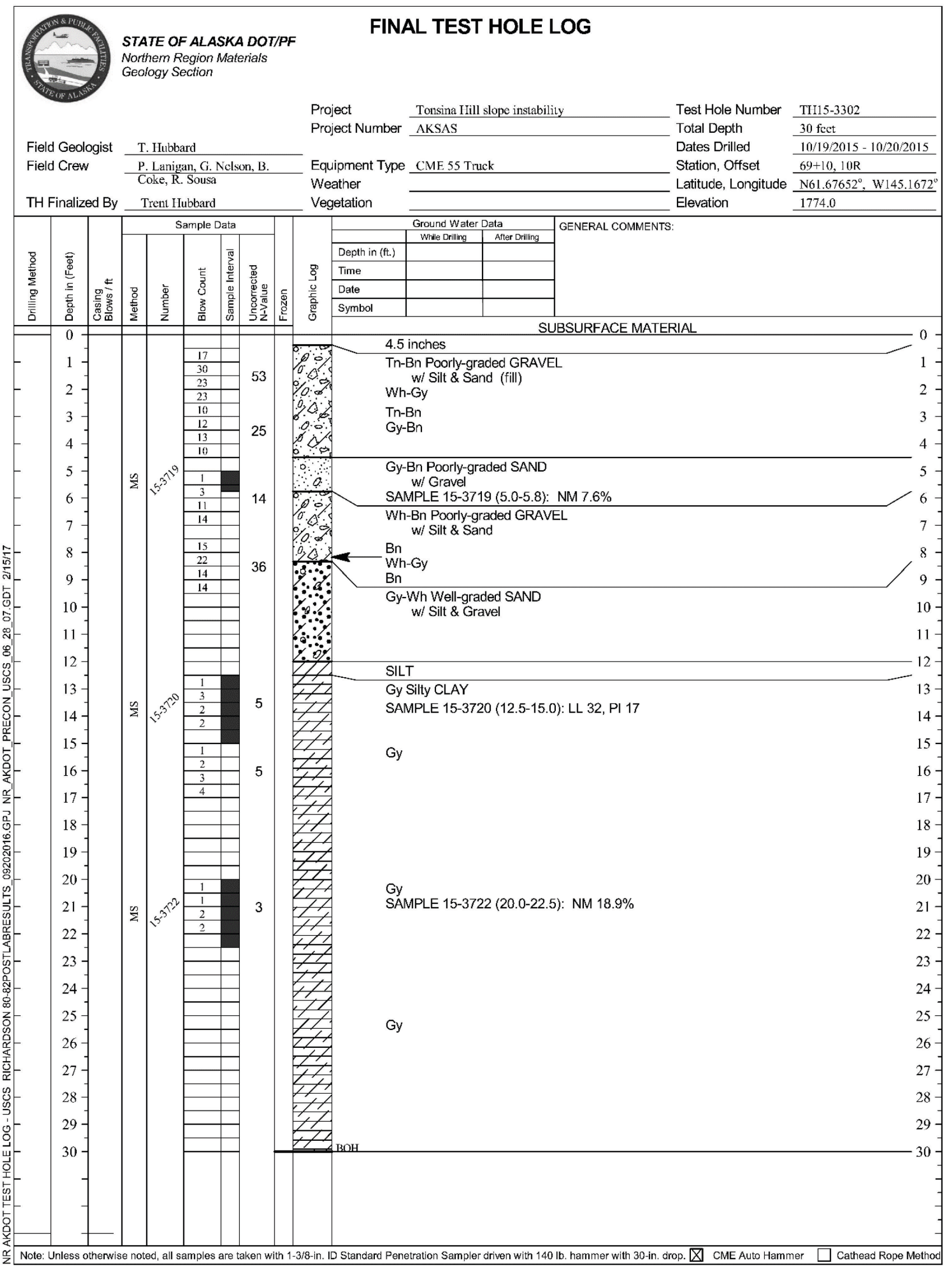




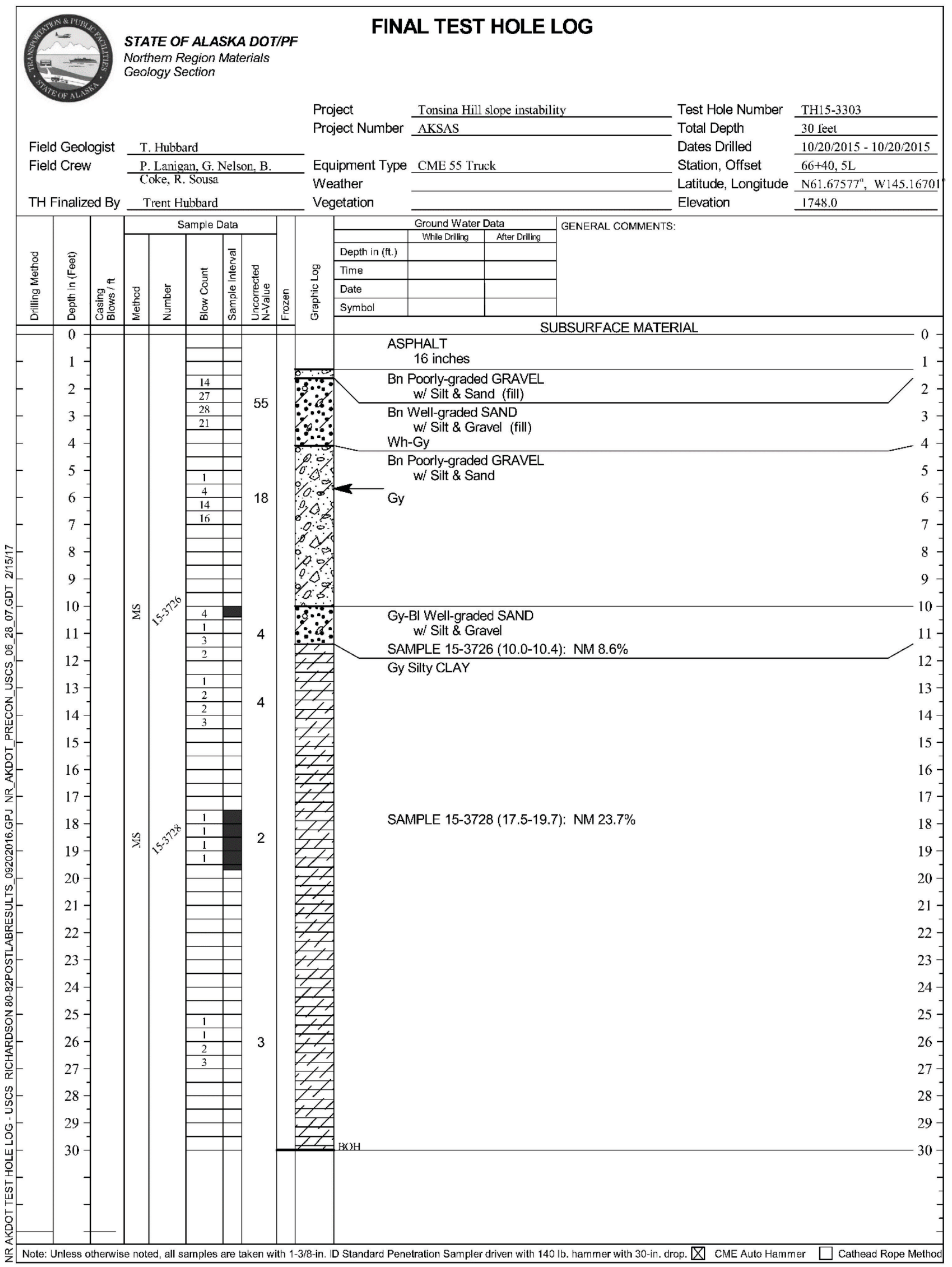




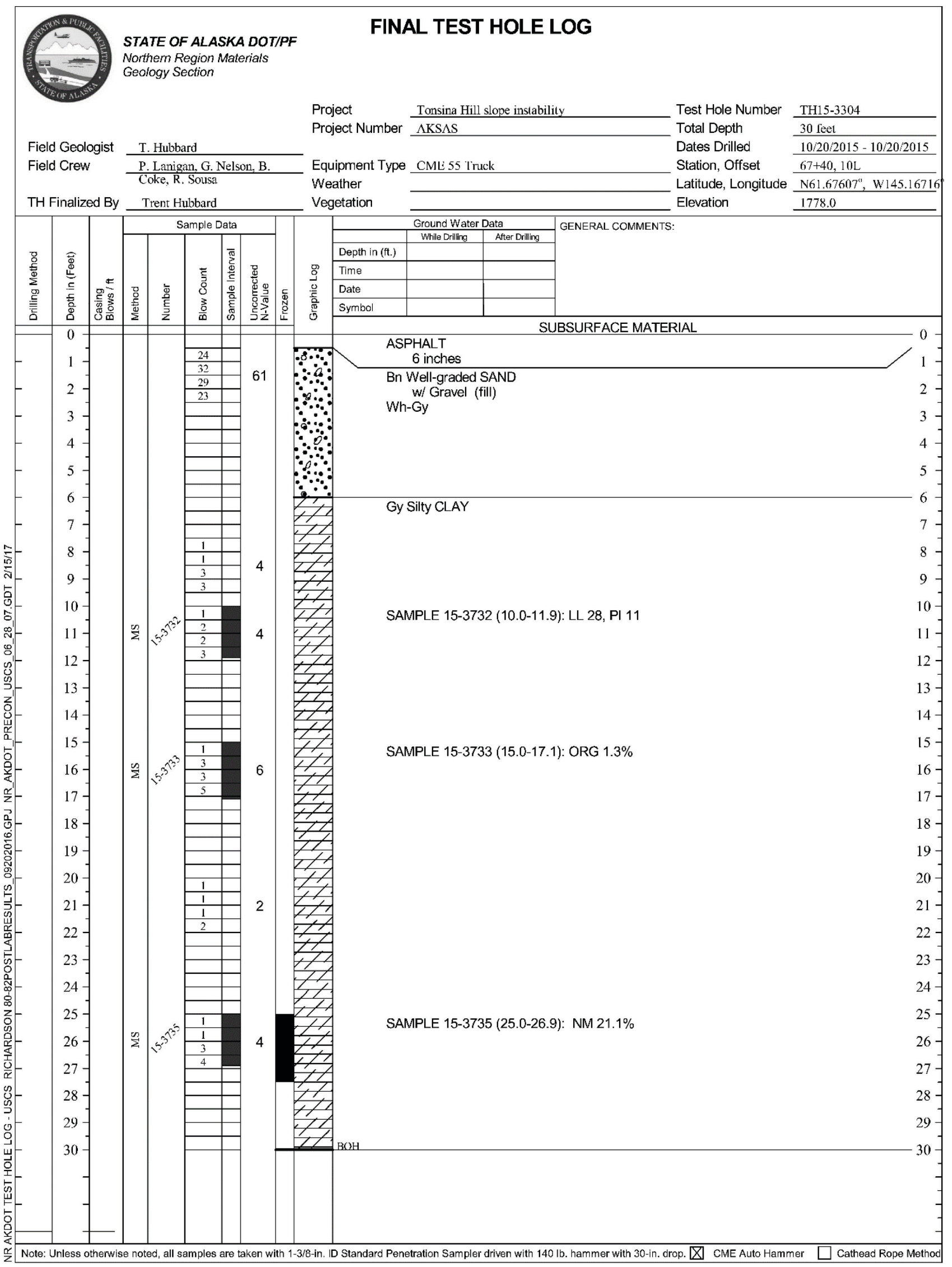




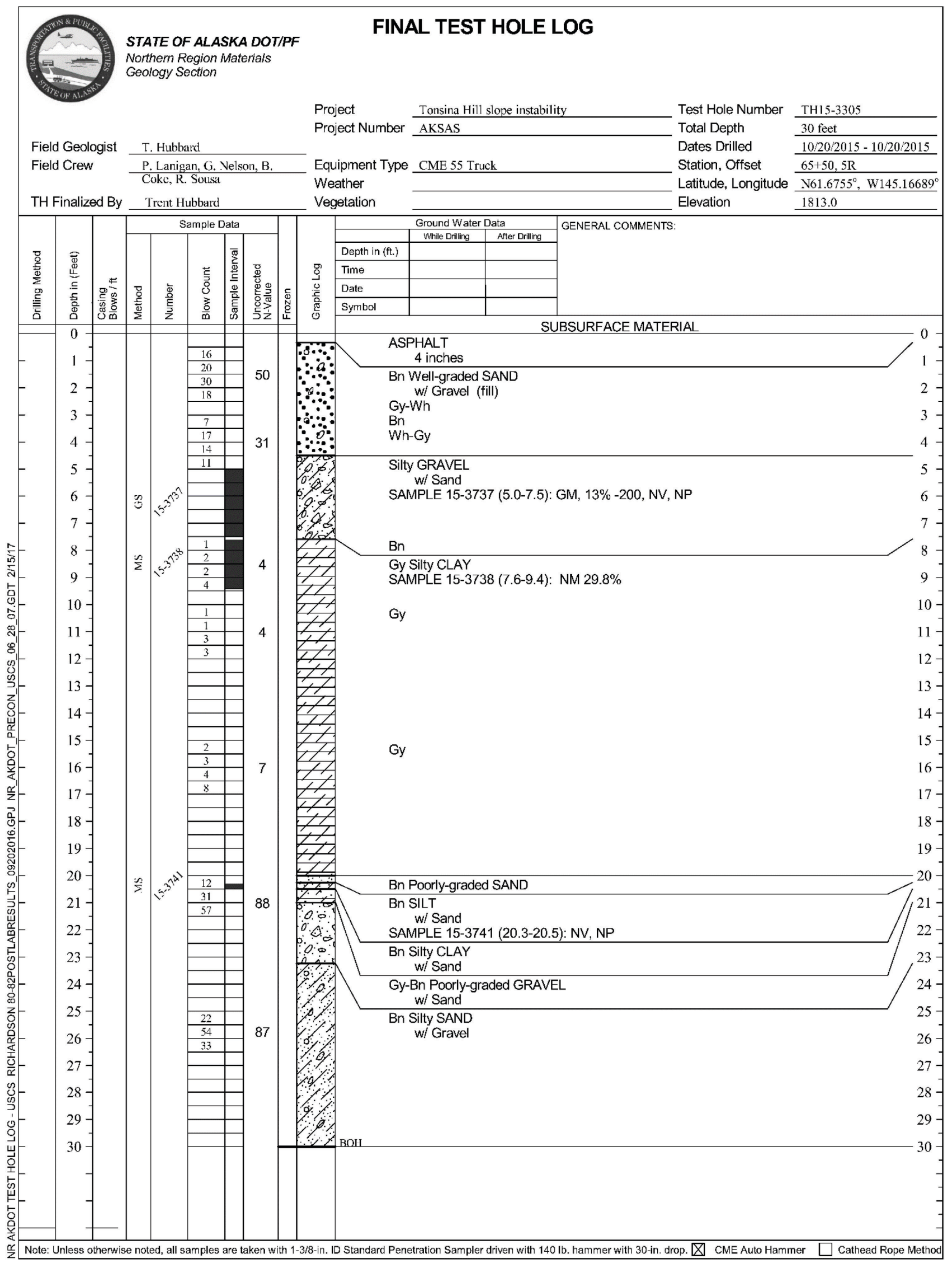




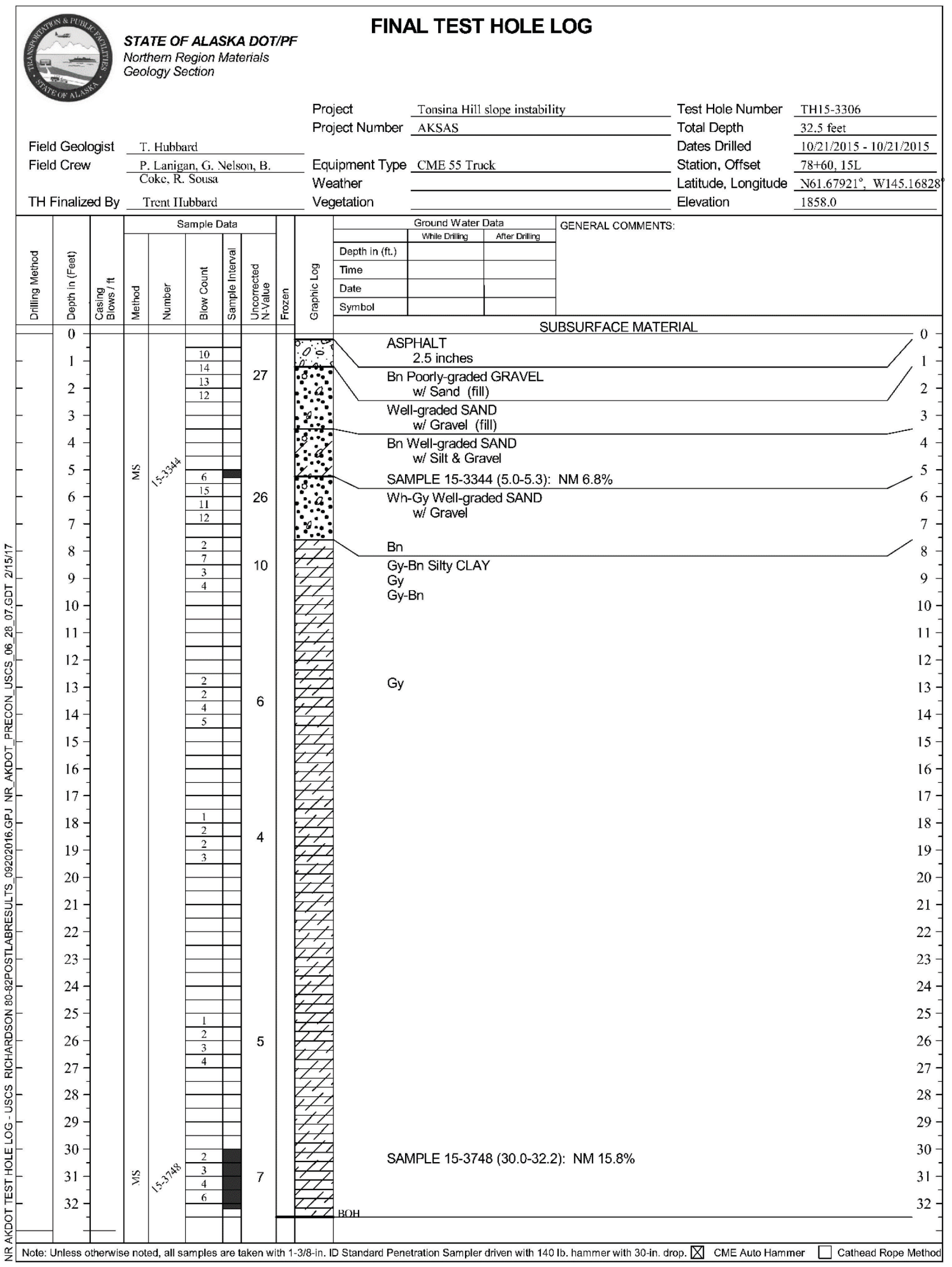




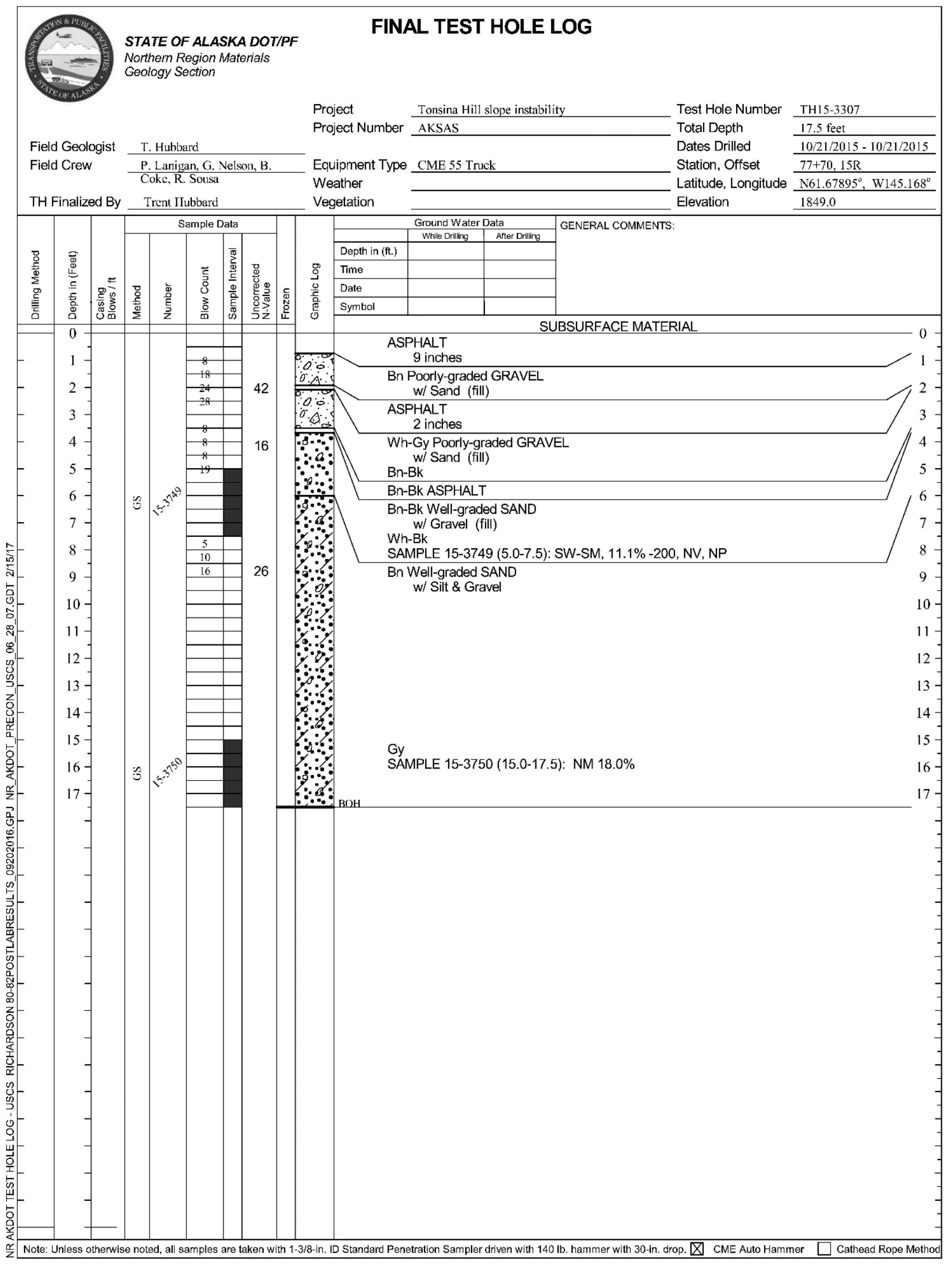




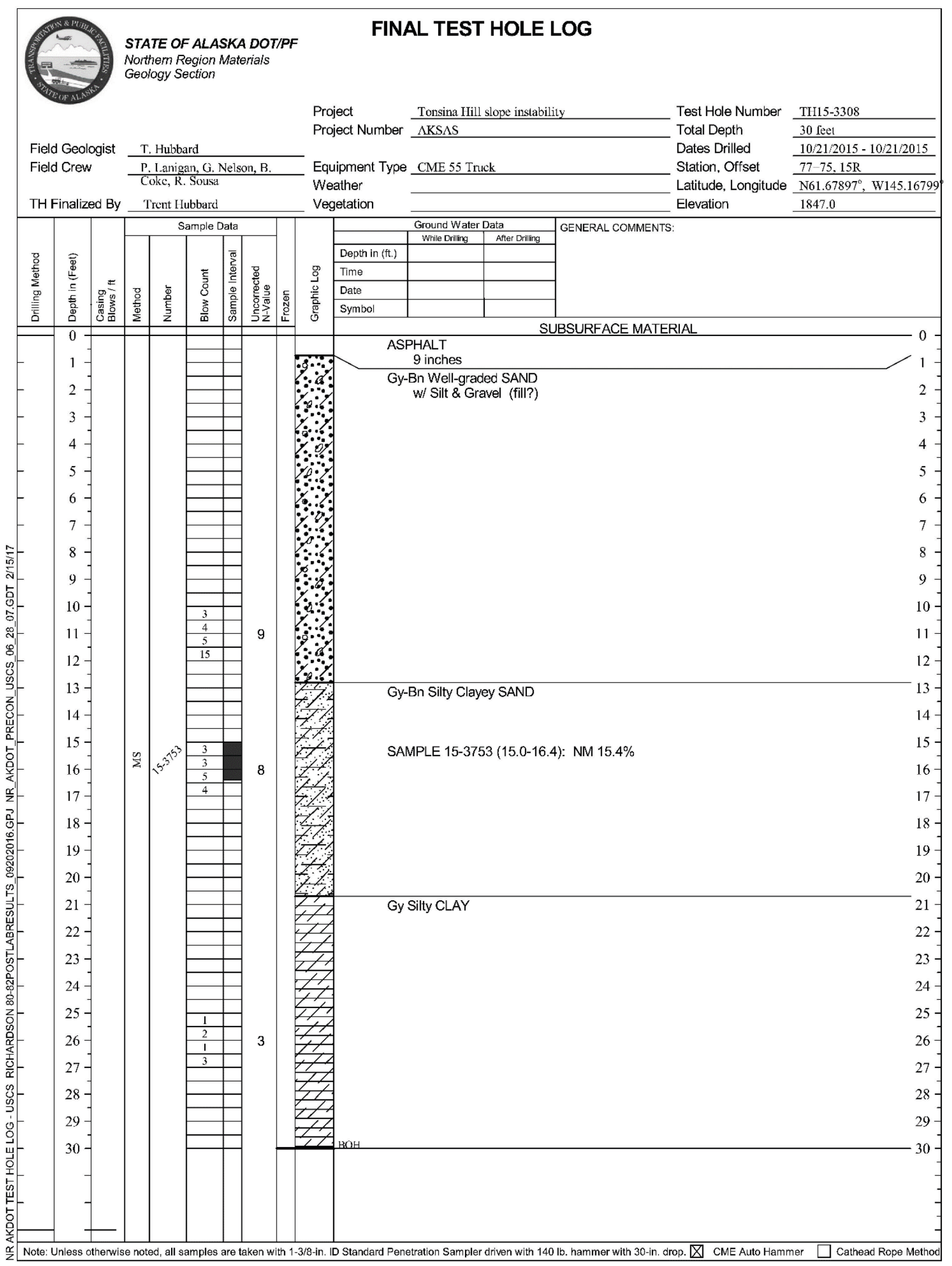




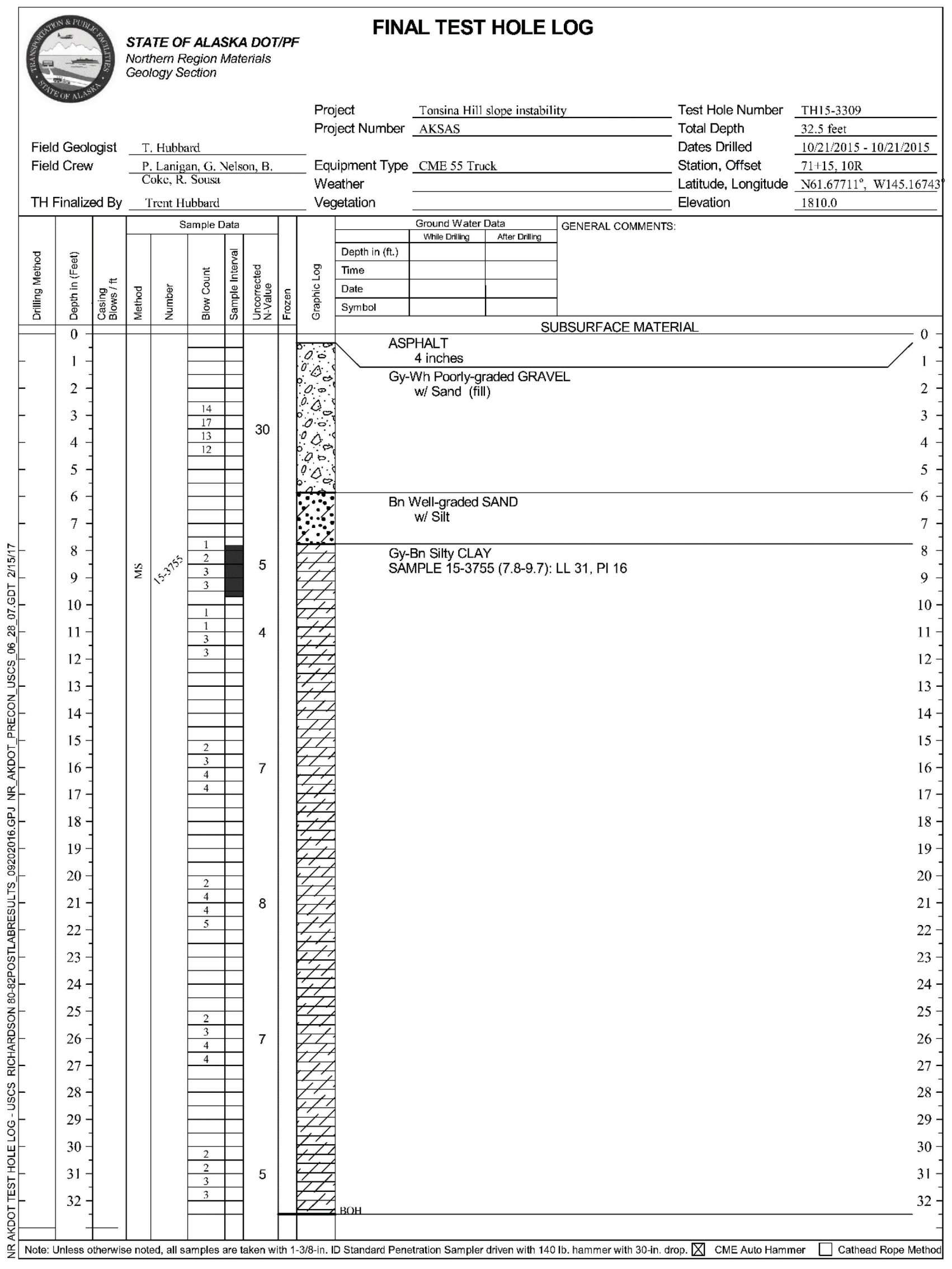




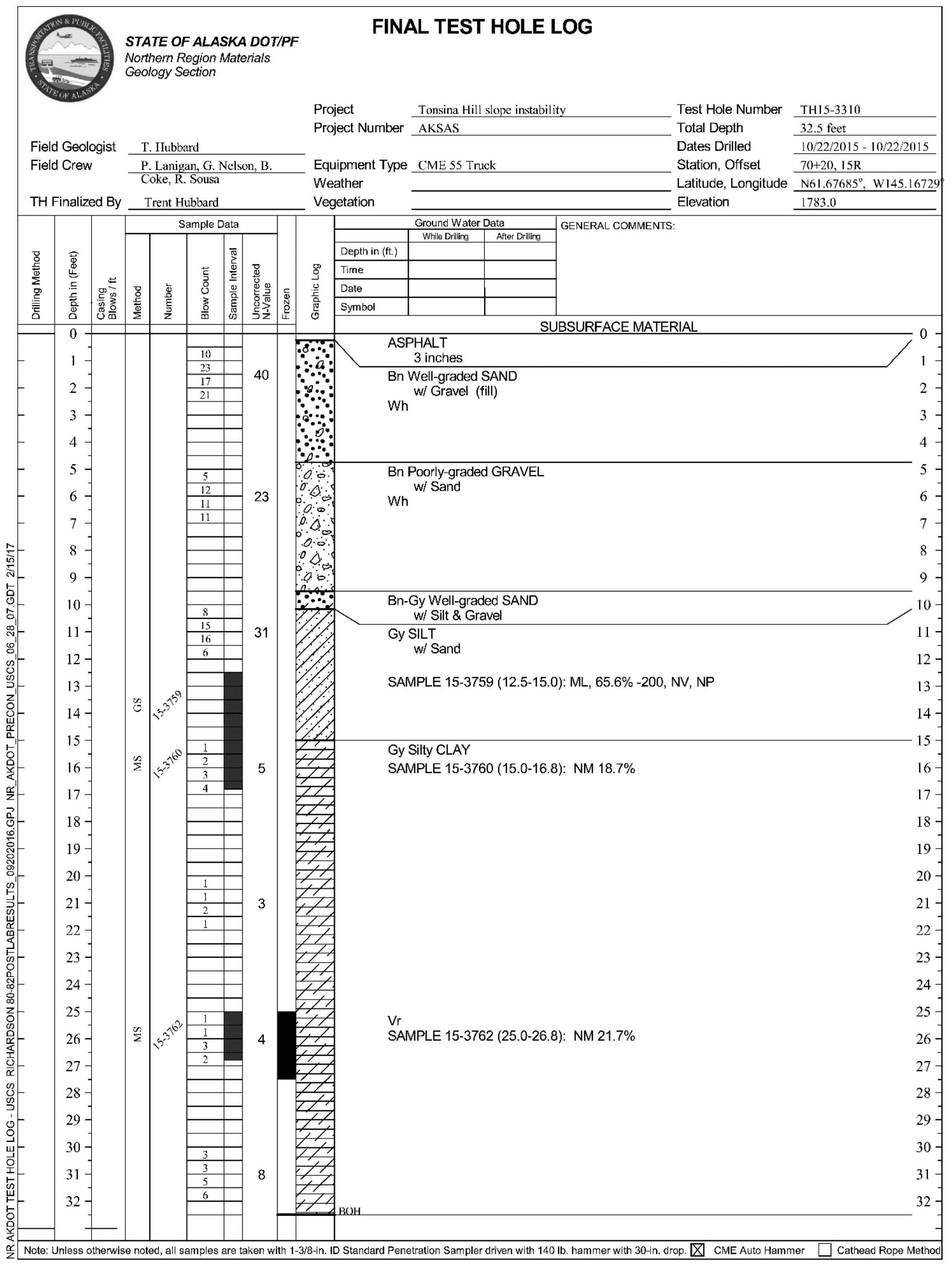




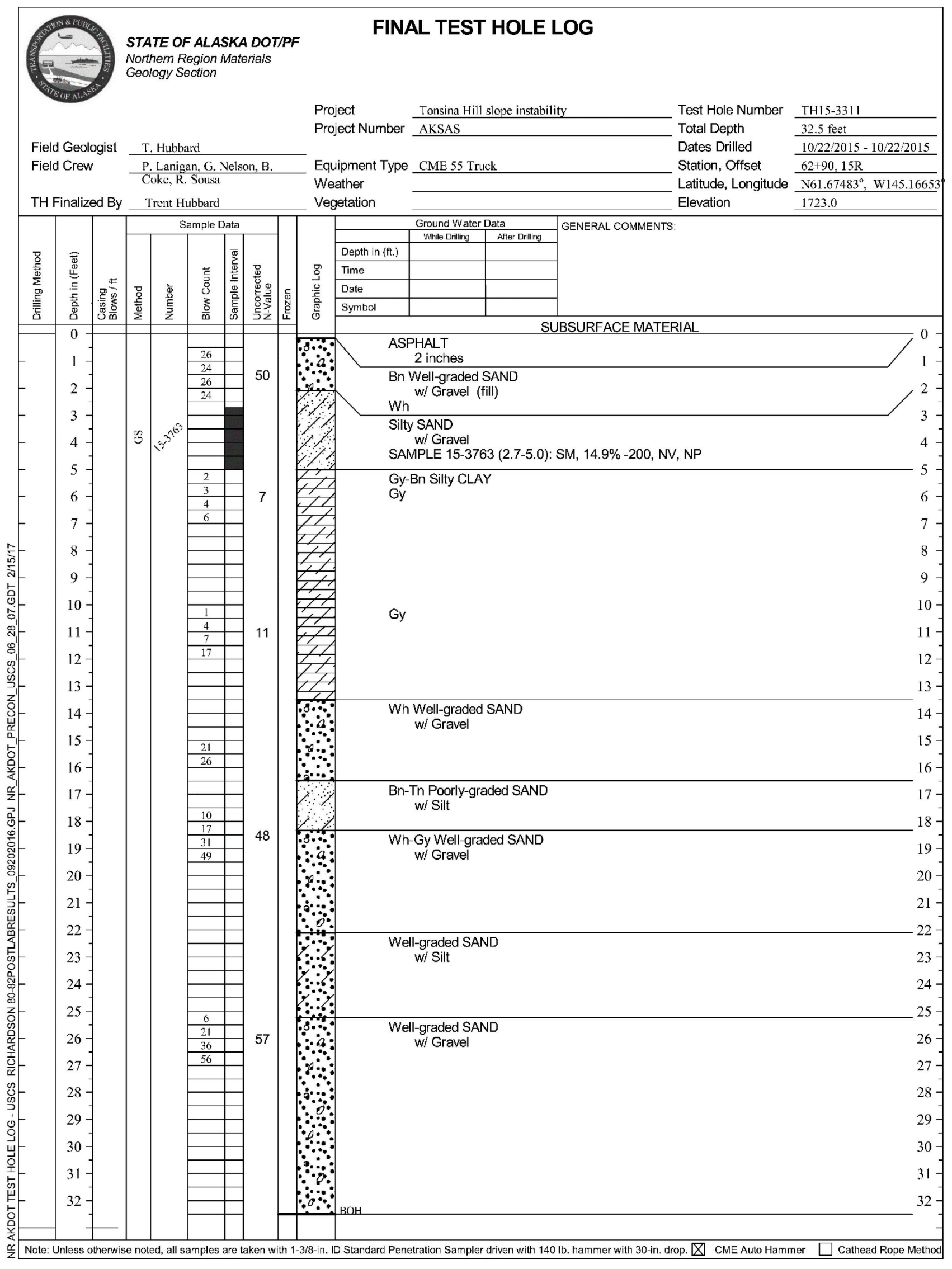




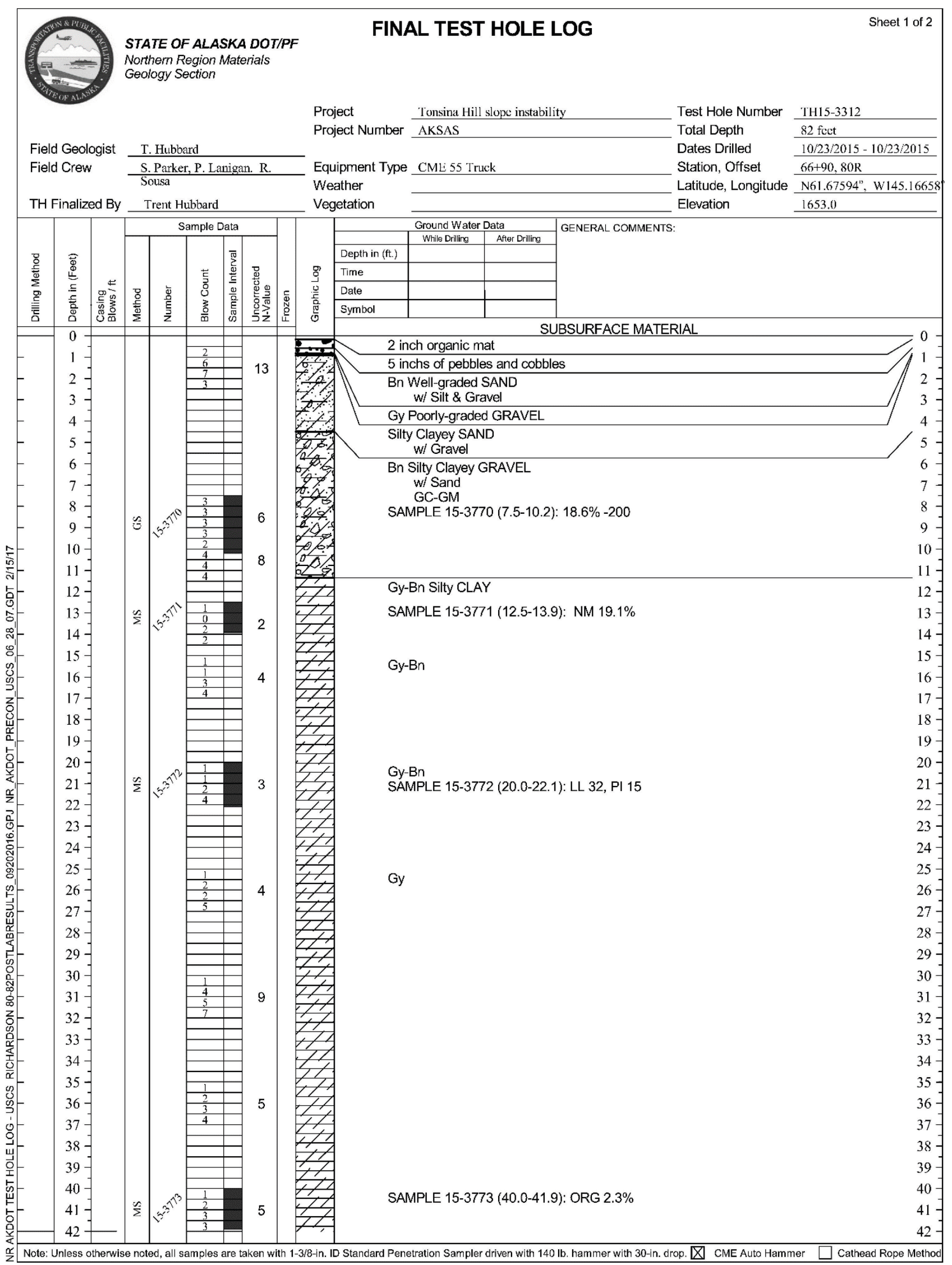




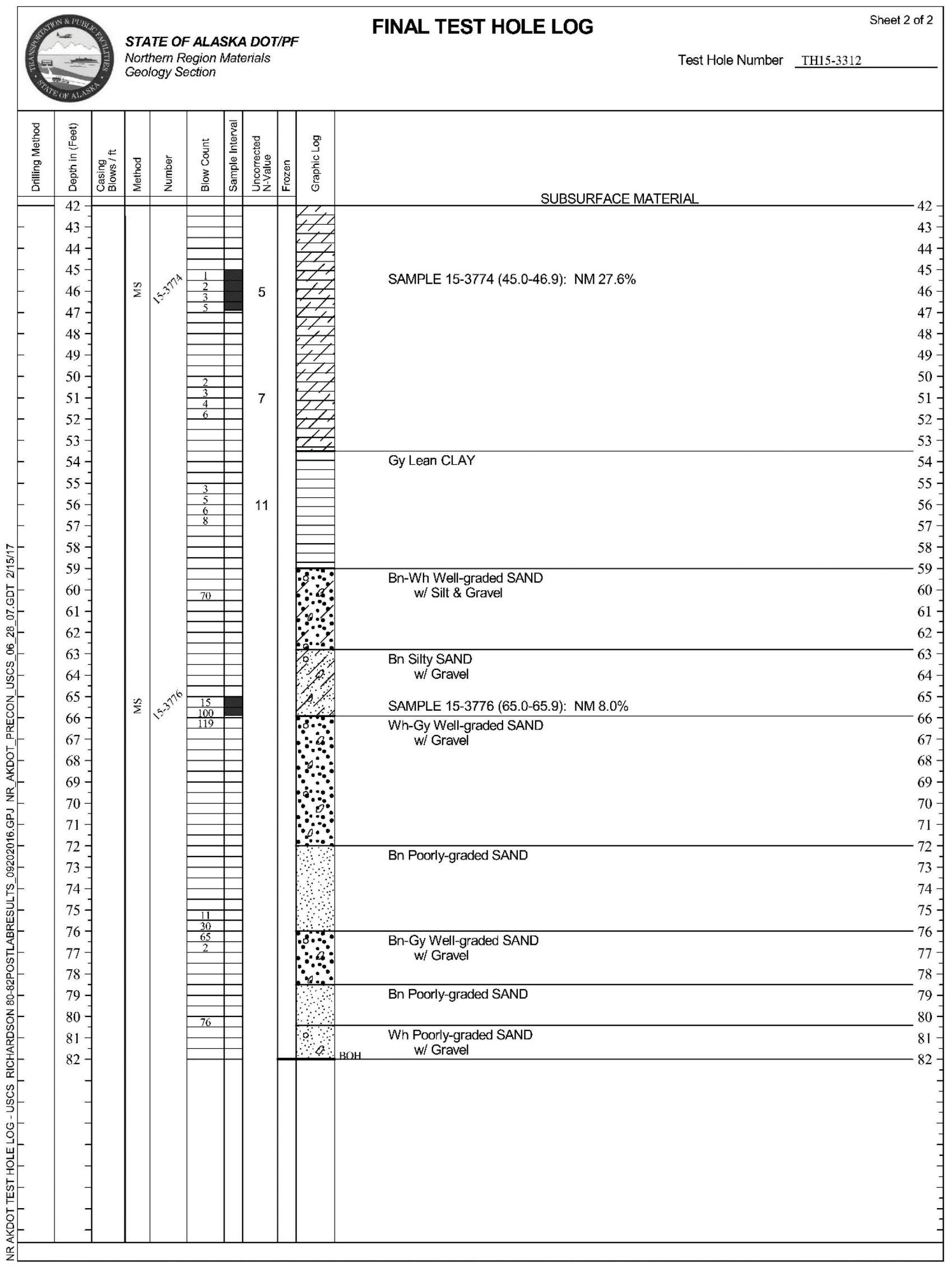




\section{APPENDIX B}

\section{LAB GRAIN SIZE ANALYSIS}

GRAIN-SIZE DISTRIBUTION CURVE

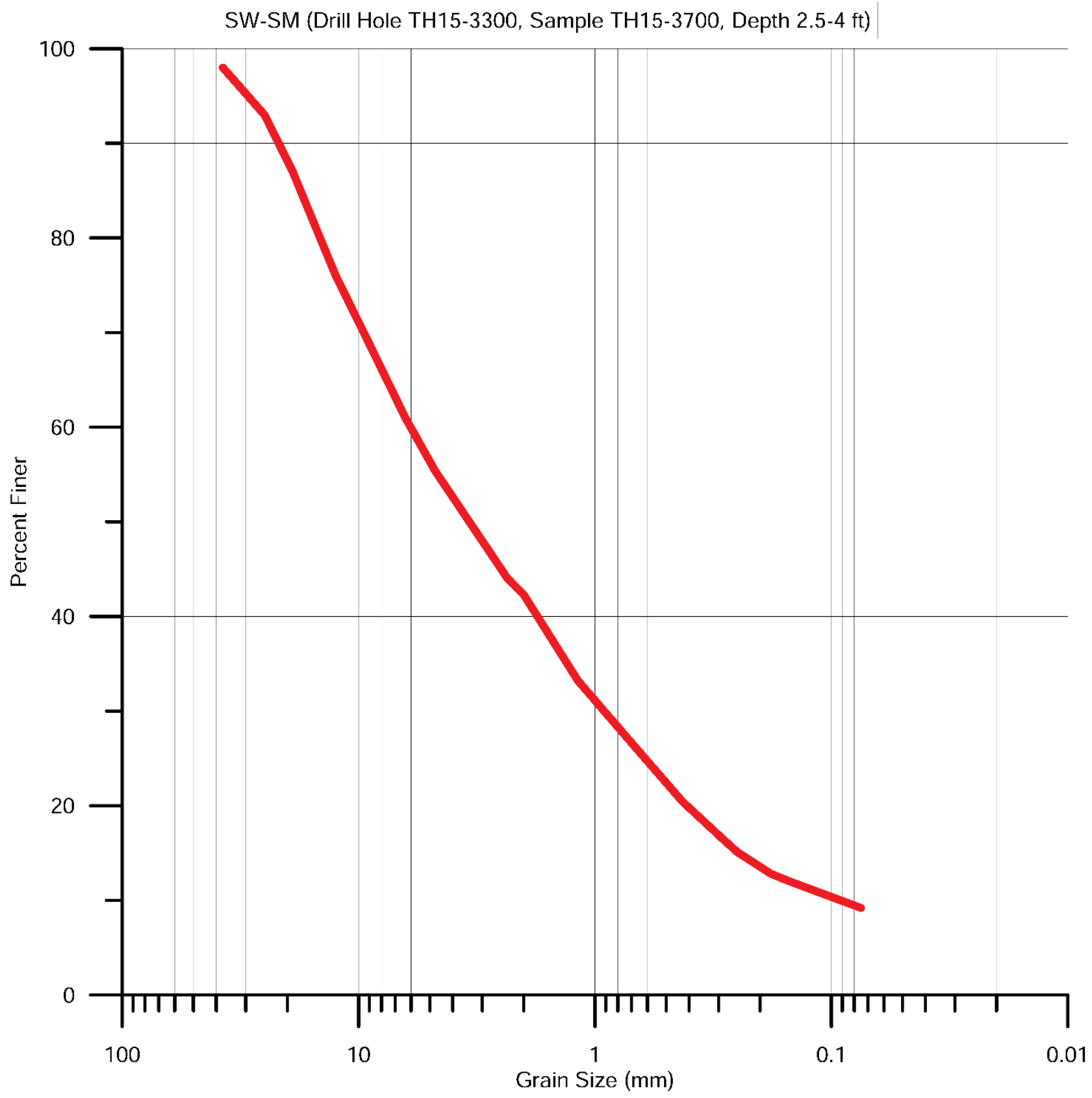


GRAIN-SIZE DISTRIBUTION CURVE

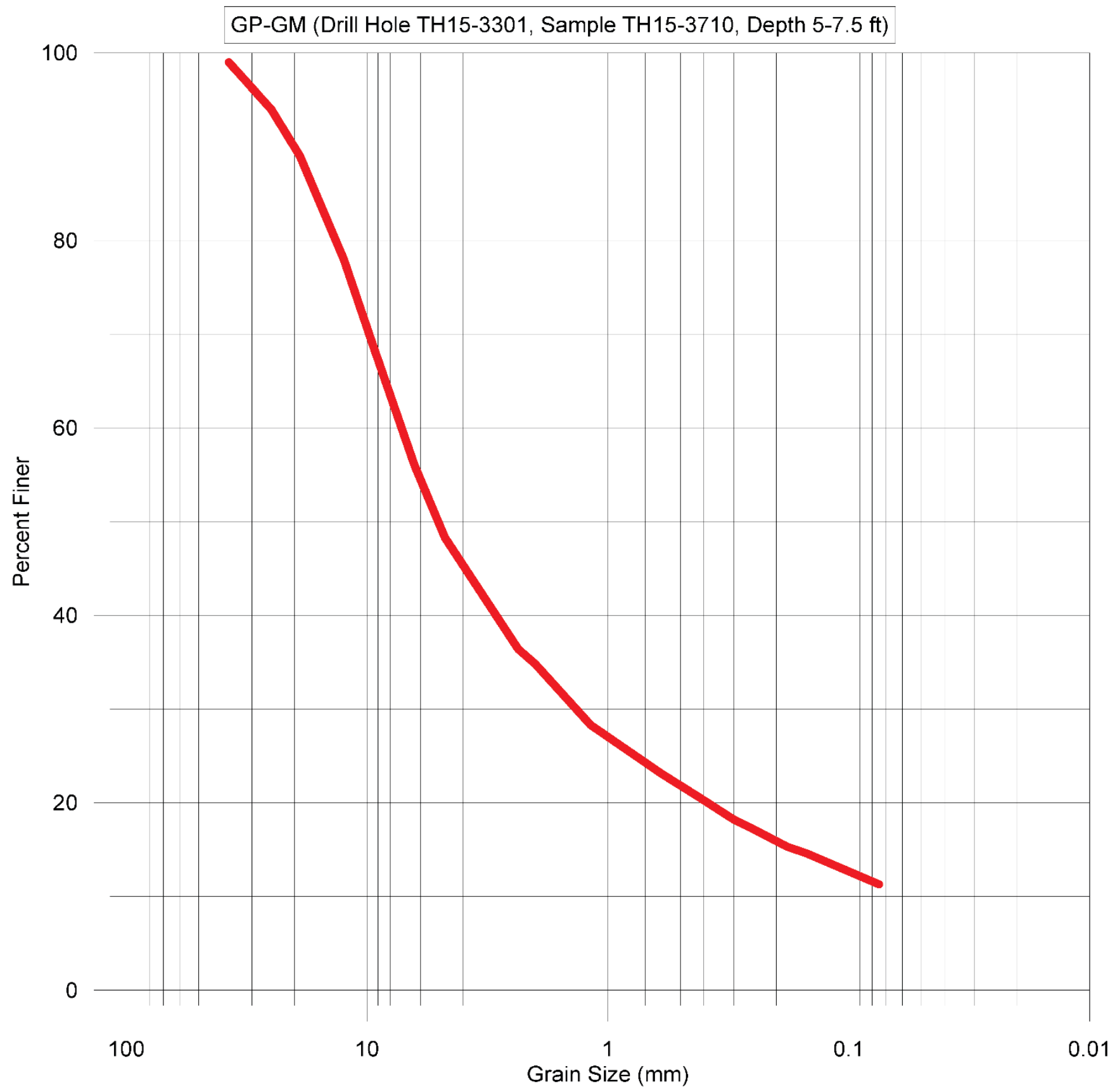


GRAIN-SIZE DISTRIBUTION CURVE

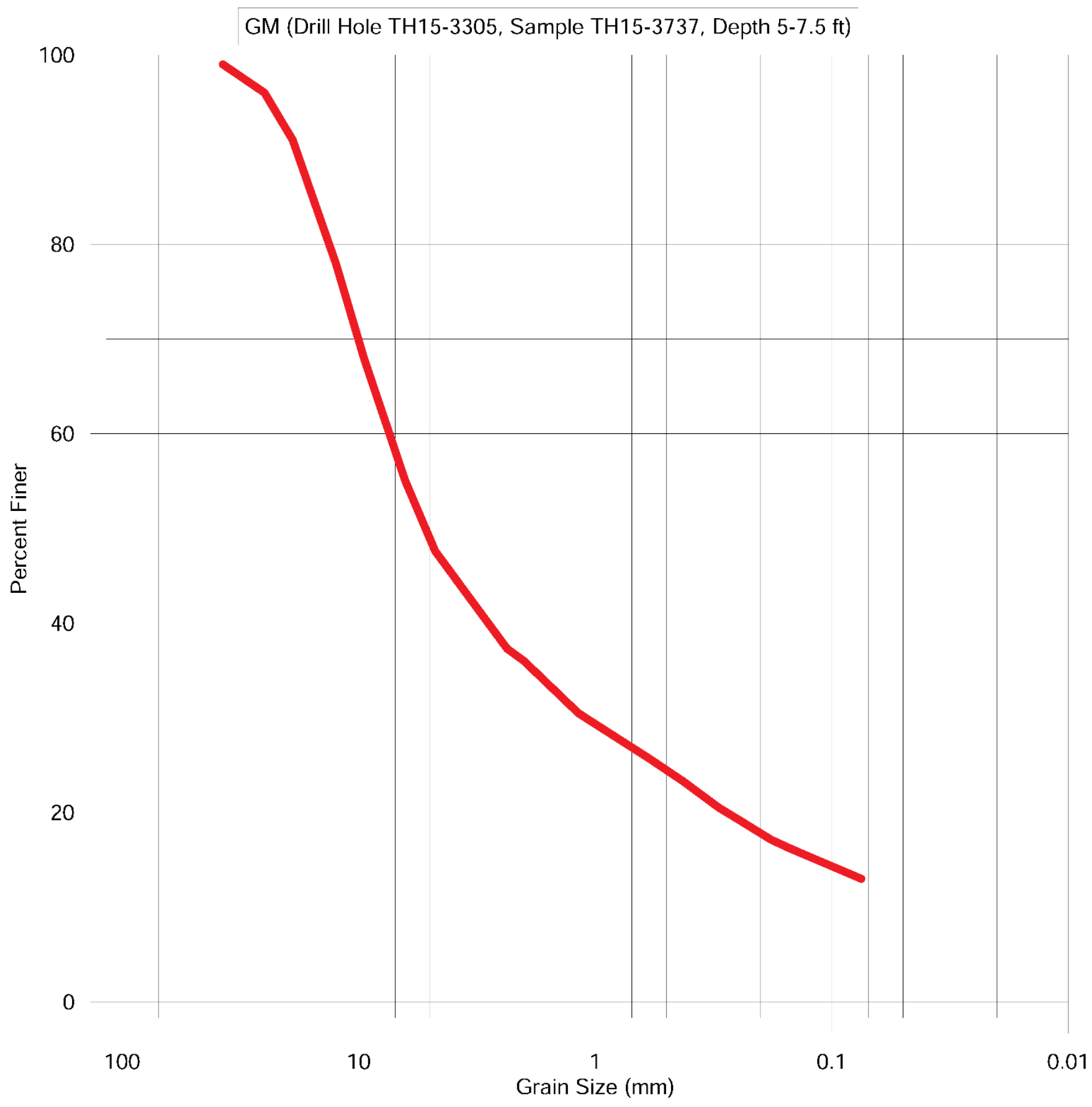




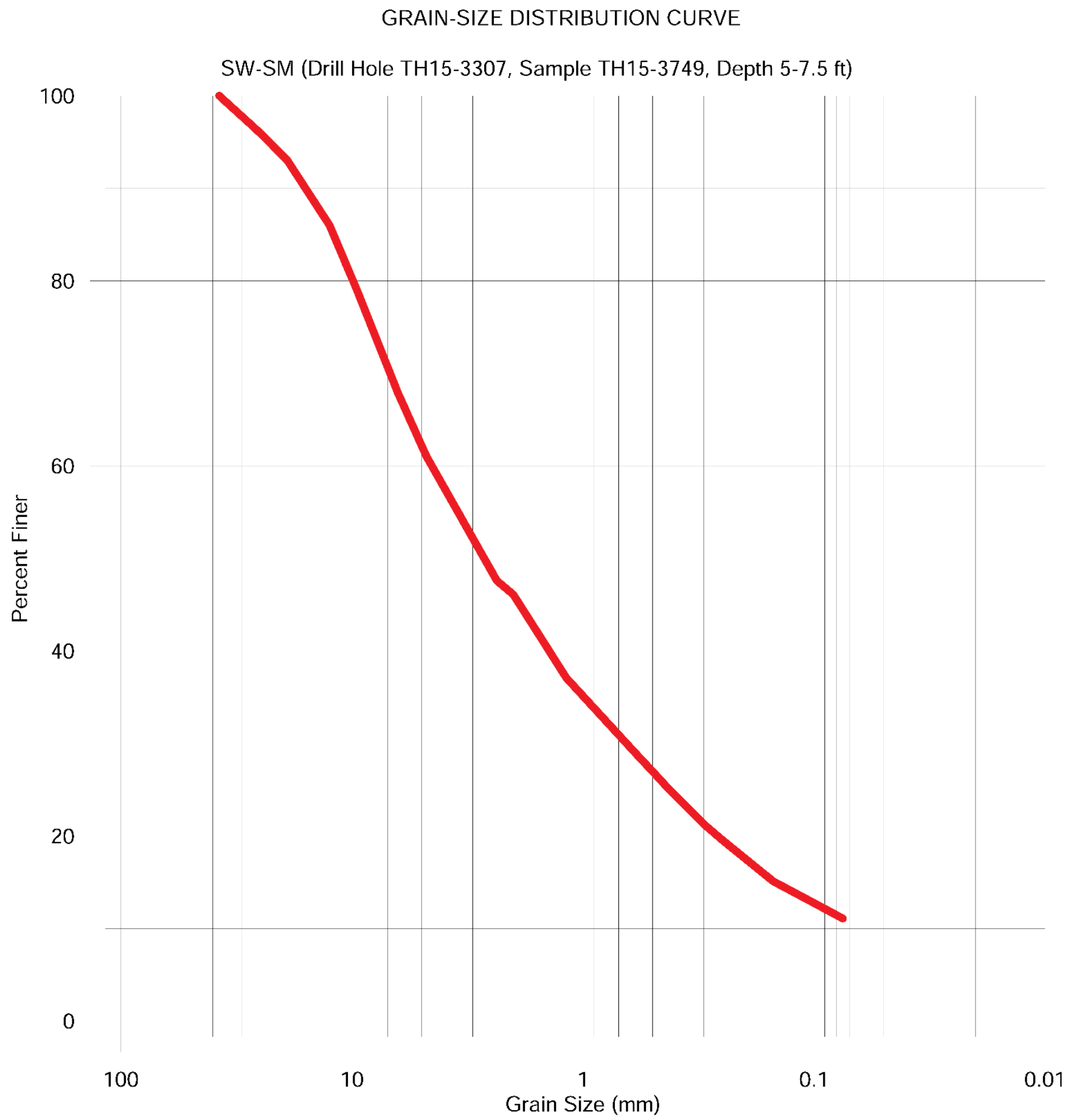




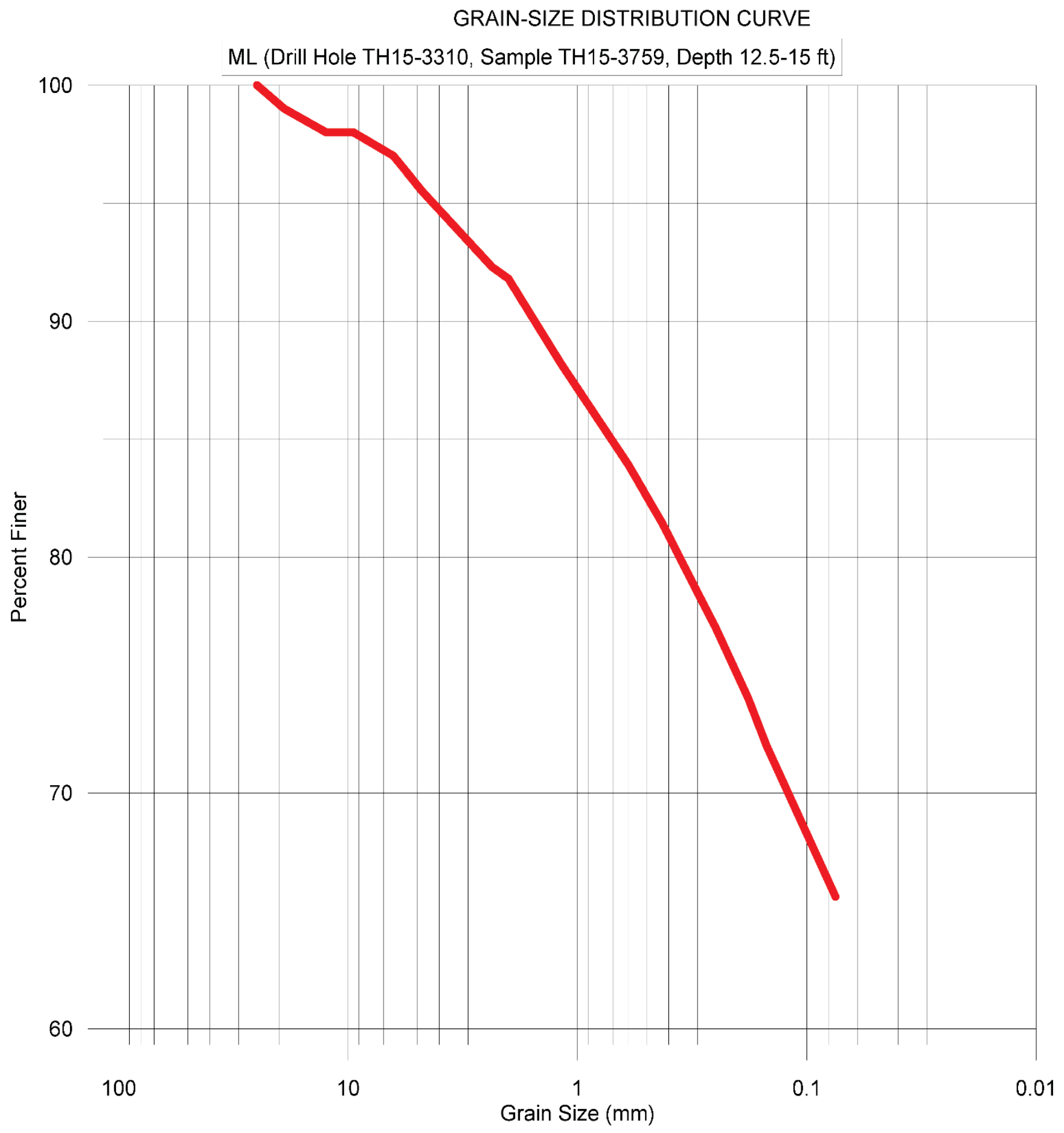




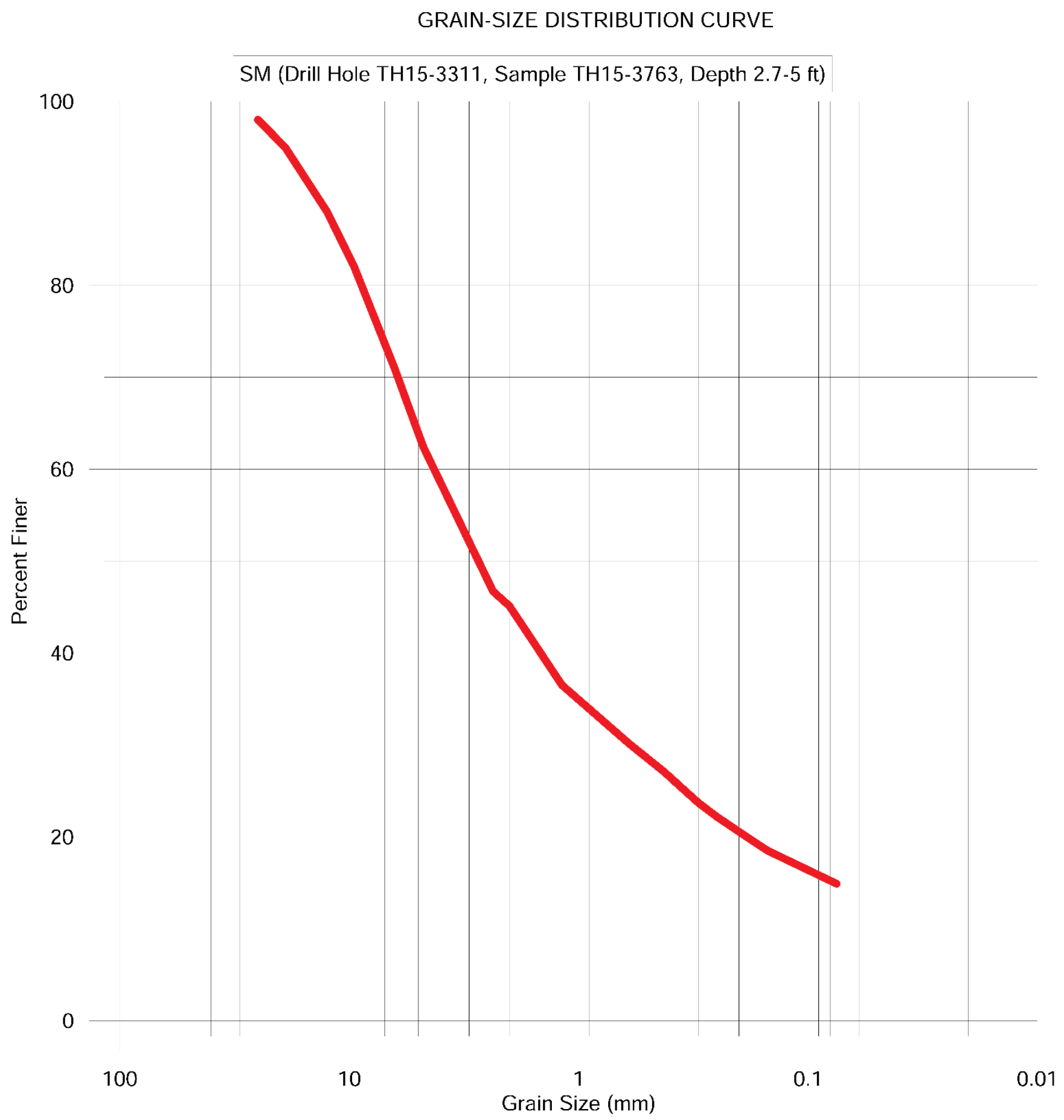




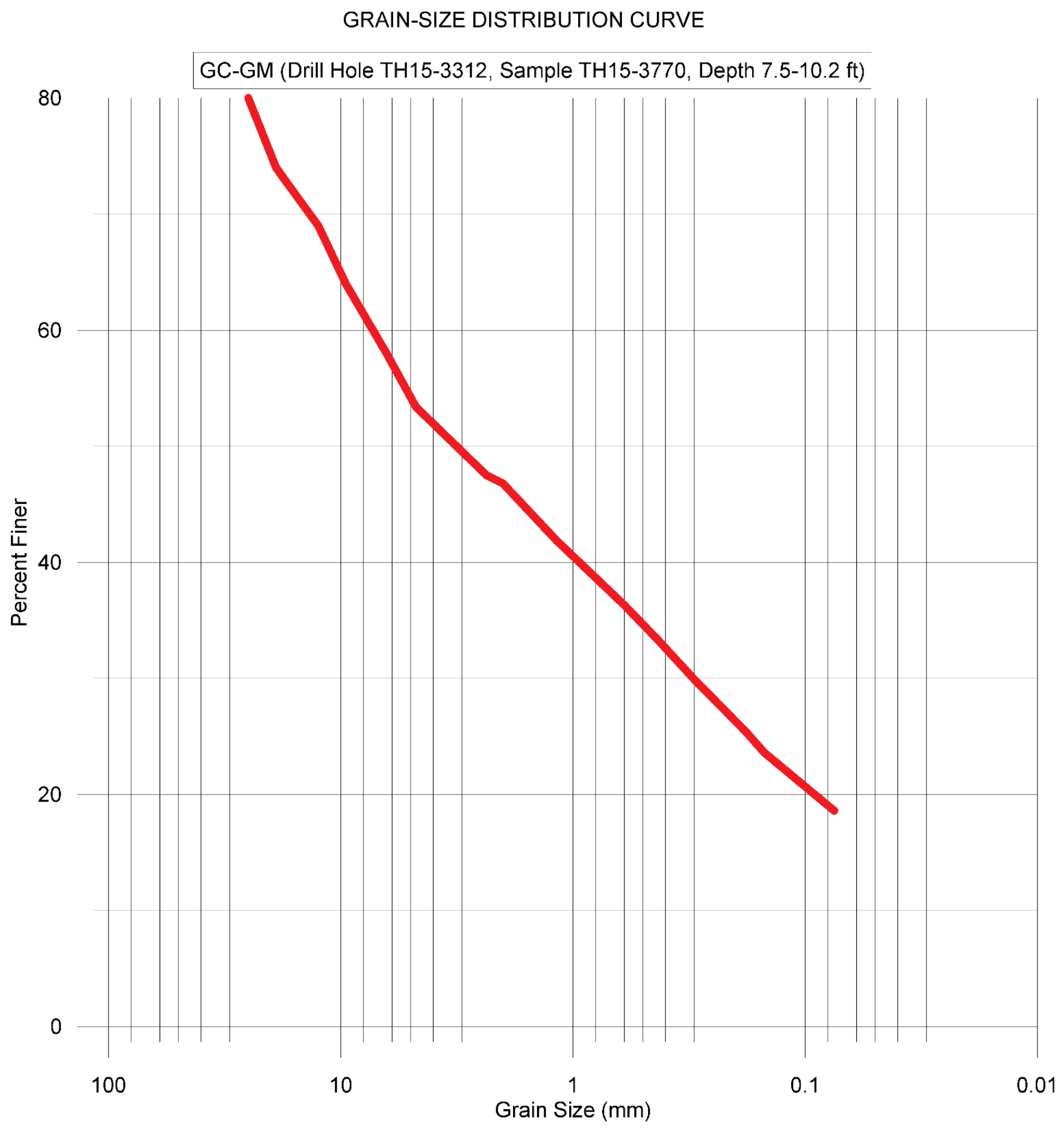




\section{APPENDIX C}

\section{MOISTURE AND ORGANIC CONTENT}

\begin{tabular}{|c|c|c|c|c|}
\hline \multirow{2}{*}{ Drill Hole } & Depth (ft) & Sample \# & $\begin{array}{c}\text { Moisture } \\
\text { Content } \\
\text { (percent) }\end{array}$ & $\begin{array}{c}\text { Organic } \\
\text { content } \\
\text { (percent) }\end{array}$ \\
\hline \multirow{3}{*}{ TH 15-3300 } & 5.8 & TH 15-3702 & 12.9 & NA \\
\cline { 2 - 5 } & 10 & TH 15-3704 & 15.1 & NA \\
\cline { 2 - 5 } & 22.5 & TH 15-3706 & NA & 2.4 \\
\hline \multirow{2}{*}{ TH 15-3301 } & 10 & TH 15-3712 & 18.4 & NA \\
\cline { 2 - 5 } & 15 & TH 15-3713 & NA & 1.4 \\
\hline \multirow{2}{*}{ TH 15-3302 } & 5 & TH 15-3719 & 7.6 & NA \\
\cline { 2 - 5 } & 20 & TH 15-3722 & 18.9 & NA \\
\hline \multirow{2}{*}{ TH 15-3303 } & 10 & TH 15-3726 & 8.6 & NA \\
\cline { 2 - 5 } & 17.5 & TH 15-3728 & 23.7 & NA \\
\hline \multirow{2}{*}{ TH 15-3304 } & 15 & TH 15-3733 & NA & 1.3 \\
\cline { 2 - 5 } & 25 & TH 15-3735 & 21.1 & NA \\
\hline TH 15-3305 & 7.6 & TH 15-3738 & 29.8 & NA \\
\hline \multirow{2}{*}{ TH 15-3306 } & 5 & TH 15-3344 & 6.8 & NA \\
\cline { 2 - 5 } & 30 & TH 15-3748 & 15.8 & NA \\
\hline TH 15-3307 & 15 & TH 15-3750 & 18.0 & NA \\
\hline TH 15-3308 & 15 & TH 15-3753 & 15.4 & NA \\
\hline \multirow{2}{*}{ TH 15-3310 } & 15 & TH 15-3760 & 18.7 & NA \\
\cline { 2 - 5 } & 25 & TH 15-3762 & 21.7 & NA \\
\hline \multirow{3}{*}{ TH 15-3312 } & 12.5 & TH 15-3771 & 19.1 & NA \\
\cline { 2 - 5 } & 40 & TH 15-3773 & NA & 2.3 \\
\cline { 2 - 5 } & 45 & TH 15-3774 & 27.6 & NA \\
\hline & 65 & TH 15-3776 & 8.0 & NA \\
\hline
\end{tabular}




\section{APPENDIX D}

\section{ATTERBERG LIMITS}

\begin{tabular}{|c|c|c|c|c|c|c|}
\hline Drill Hole & $\begin{array}{c}\text { Depth } \\
\text { (ft) }\end{array}$ & Sample \# & Liquid Limit (LL) & $\begin{array}{l}\text { Plastic Limit } \\
\text { (PL) }\end{array}$ & $\begin{array}{l}\text { Plasticity Index* } \\
\text { (PI) }\end{array}$ & Plasticity Classification \\
\hline TH 15-3300 & 7.5 & TH 15-3703 & 27.04926 & 13.32133 & 13.72793 & Medium Plasticity \\
\hline TH 15-3301 & 20 & TH 15-3714 & 34.68658 & 21.53361 & 13.15297 & Medium Plasticity \\
\hline TH 15-3302 & 12.5 & TH $15-3720$ & 32.1485 & 15.41582 & 16.73268 & Medium Plasticity \\
\hline TH 15-3304 & 10 & TH 15-3732 & 28.44893 & 17.2448 & 11.20413 & Medium Plasticity \\
\hline TH 15-3309 & 7.5 & TH 15-3755 & 30.79326 & 14.95685 & 15.83641 & Medium Plasticity \\
\hline TH 15-3312 & 20 & TH 15-3772 & 31.737 & 16.71442 & 15.02258 & Medium Plasticity \\
\hline & & $* \mathrm{PI}=\mathrm{LL}-\mathrm{PL}$ & $\begin{array}{c}0 \\
1-5 \\
5-10 \\
10-20 \\
20-40 \\
>40\end{array}$ & $\begin{array}{l}\text { nonplastic } \\
\text { slightly plastic } \\
\text { low plasticity } \\
\text { medium plasticity } \\
\text { high plasticity } \\
\text { very high plasticity }\end{array}$ & & \\
\hline
\end{tabular}


APPENDIX E

DRILL HOLE TEMPERATURE DATA

\begin{tabular}{|c|c|c|}
\hline Drill Hole & Depth (ft) & Temperature $\left({ }^{\circ} \mathrm{F}\right)$ \\
\hline \multirow{2}{*}{ TH 15-3300 } & 7.5 & 44.8 \\
\hline & 20.0 & 45.5 \\
\hline \multirow{2}{*}{ TH 15-3301 } & 15.0 & 44.0 \\
\hline & 25.0 & 44.0 \\
\hline \multirow{2}{*}{ TH 15-3302 } & 15.0 & 40.5 \\
\hline & 27.5 & 34.3 \\
\hline \multirow{2}{*}{ TH 15-3303 } & 12.5 & 39.4 \\
\hline & 17.5 & 36.0 \\
\hline \multirow{5}{*}{ TH 15-3304 } & 7.5 & 40.0 \\
\hline & 10.0 & 39.5 \\
\hline & 15.0 & 39.7 \\
\hline & 5.0 & 39.1 \\
\hline & 30.0 & 32.1 \\
\hline \multirow{3}{*}{ TH 15-3305 } & 7.5 & 42.0 \\
\hline & 10.0 & 44.0 \\
\hline & 20.3 & 40.0 \\
\hline \multirow{2}{*}{ TH 15-3306 } & 17.5 & 40.0 \\
\hline & 30.0 & 36.1 \\
\hline \multicolumn{3}{|l|}{ TH 15-3307 } \\
\hline TH 15-3308 & 25.0 & 40.0 \\
\hline \multirow{6}{*}{ TH 15-3309 } & 7.5 & 42.0 \\
\hline & 10.0 & 42.1 \\
\hline & 15.0 & 39.9 \\
\hline & 20.0 & 38.0 \\
\hline & 25.0 & 37.6 \\
\hline & 30.0 & 35.5 \\
\hline \multirow{4}{*}{ TH 15-3310 } & 15.0 & 38.0 \\
\hline & 20.0 & 35.2 \\
\hline & 25.0 & 31.1 \\
\hline & 30.0 & 34.1 \\
\hline TH 15-3311 & 10.0 & 41.5 \\
\hline \multirow{10}{*}{ TH 15-3312 } & 12.5 & 34.8 \\
\hline & 15.0 & 41.0 \\
\hline & 20.0 & 40.6 \\
\hline & 25.0 & 38.3 \\
\hline & 30.0 & 38.1 \\
\hline & 35.0 & 38.9 \\
\hline & 40.0 & 39.2 \\
\hline & 45.0 & 39.2 \\
\hline & 50.0 & 39.6 \\
\hline & 55.0 & 44.7 \\
\hline
\end{tabular}

